\title{
Role of the Jet Angle, Particle Size, and Particle Concentration in the Degradation Behavior of Carbon Steel under Slow Slurry Erosion-Corrosion Conditions
}

\author{
Charles Rasse ${ }^{1}$, Nicolas Mary ${ }^{2, *(D)}$, Hiroshi Abe ${ }^{1}$, Yutaka Watanabe ${ }^{1,2}$ and Bernard Normand ${ }^{3}(\mathbb{D}$ \\ 1 Graduate School of Engineering, Tohoku University, 6-6-01-2 Aoba, Aramaki, Aoba-Ku, \\ Sendai 980-8579, Japan; charles.rasse@utt.fr (C.R.); hiroshi.abe@qse.tohoku.ac.jp (H.A.); \\ yutaka.watanabe@qse.tohoku.ac.jp (Y.W.) \\ 2 International Research Laboratory, ELyTMaX UMI 3757, CNRS, Université de Lyon, Tohoku University, \\ Sendai 980-8576, Japan \\ 3 INSA-Lyon, MATEIS UMR CNRS 5510, Université Lyon, F-69621 Villeurbanne, France; \\ bernard.normand@insa-lyon.fr \\ * Correspondence: nicolas.mary@insa-lyon.fr
}

Citation: Rasse, C.; Mary, N.; Abe, H.; Watanabe, Y.; Normand, B. Role of the Jet Angle, Particle Size, and Particle Concentration in the Degradation Behavior of Carbon Steel under Slow Slurry Erosion-Corrosion Conditions. Metals 2021, 11, 1152. https://doi.org/10.3390/met11081152

Academic Editor: Marcello Cabibbo

Received: 8 June 2021

Accepted: 15 July 2021

Published: 21 July 2021

Publisher's Note: MDPI stays neutral with regard to jurisdictional claims in published maps and institutional affiliations.

Copyright: (c) 2021 by the authors. Licensee MDPI, Basel, Switzerland. This article is an open access article distributed under the terms and conditions of the Creative Commons Attribution (CC BY) license (https:/ / creativecommons.org/licenses/by/ $4.0 /)$.

\begin{abstract}
Erosion-corrosion behavior of piping systems is a critical issue for their durability. This work concerns the erosion-corrosion behavior of carbon steel as a function of abradant characteristics as particle size and concentration. Degradation tests were performed in a jet erosion-corrosion cell with a maximum flow rate of $4.8 \mathrm{~m} / \mathrm{s}$, and jet angles comprised $30^{\circ}$ and $90^{\circ}$. Abradant particles consisted of angular alumina powder with a mean diameter of 181,219 , and $359 \mu \mathrm{m}$. A critical threshold flow velocity of about $2.5 \mathrm{~m} / \mathrm{s}$ was determined when experiments were performed with particles with diameters of $181 \mu \mathrm{m}$ and jet angles of $45^{\circ}$. Even if erosion did not occur, the degradation rate increased compared with the stagnant condition because of dissolved dioxygen supply. A maximum of erosion-corrosion of $4 \mathrm{mg} \times \mathrm{cm}^{-2} \times \mathrm{h}^{-1}$ was determined for the jet angle of $45^{\circ}$, irrespective of the particle sizes. The increase of abradant concentration led to a higher degradation rate regardless of the jet angle. However, the degradation rates tended to limit values of $7 \mathrm{mg} \times \mathrm{cm}^{-2} \times \mathrm{h}^{-1}$ at $45^{\circ}$ and $5 \mathrm{mg} \times \mathrm{cm}^{-2} \times \mathrm{h}^{-1}$ at $90^{\circ}$. Above a critical concentration, a slowdown of the degradation was measured, suggesting that particle behavior in dense fluid acts on material degradation. This critical concentration can be understood from the interactions of the particles in concentrated media that modify trajectories in the flow and at the metal surface, reducing their kinetic energy consequently.
\end{abstract}

Keywords: erosion; corrosion; abradant concentration; carbon steel

\section{Introduction}

Turbomachinery, short and long-distance pipelines, pumps, etc., are constitutive to fluid transportation structures. Because the fluids can contain hard particles, materials are submitted to abrasion, erosion, and corrosion. Slurry erosion and slurry erosion-corrosion behavior of materials depend on environmental and experimental conditions. For passive materials such as stainless steel, the synergistic effect between erosion and corrosion is expected since the passive is scratched by the particles and rebuilt shortly after [1]. In carbon steels, the oxide film is less resistant, the mechanic usually dominates the matter loss, and the hardest phase is more effective in erosion resistance [2-4]. However, the material potential and the solution temperature can play a role in the transitions between erosion-corrosion regimes, as Stack et al. [5] showed.

Often, eroded and abraded metallic surfaces show similarities. However, a separation based on the mechanical-wear process is made [5]: abrasion does not require the impingement of hard particles to generate a material loss, whereas erosion deals with the kinetic energy transfer of hard particles to the substrate [6]. Consequently, shorter contact times between particles and substrate are expected in erosion than in abrasion [7]. Slurry erosion 
(SE) or erosion-corrosion (SEC) occurs when abrasive particles are transported in a fluid, gas, or liquid, respectively. In the case of SEC, the mechanical degradation due to collisions is added to the corrosivity of the solution. Wood et al. provided the main variables acting in slurry erosion. It concerns the liquid (density, temperature, viscosity, corrosivity, etc.), the particles (hardness, density, velocity, sharpness), the flow field (angle of impingement, boundary layer), the substrate metallurgy, and surface properties [8].

Erosion and erosion-corrosion tests are performed at the lab scale with a slurry pot or slurry jet cells [6]. In a slurry pot, the sample rotates inside a cylindrical tank. Particular attention is paid to particle flow and vortex generation due to cell design [9]. Conversely, jet erosion cells are based on the abradant spraying on the sample surface through a nozzle installed in a circulation loop. Further details are available in [4,6]. Recently instrumented pipes or pipe elbows have been developed to discuss the influence of flow and particle distribution on the erosion rate. Metallic samples were mounted in a polymer pipe, and CFD calculations were carried out to select the right places for the electrode array [1,10-12]. Because particle velocity and impact angles are better controlled in jet erosion cellule, the latter is preferred to rank materials or understand the erosion or erosion-corrosion behavior of materials versus the slurry characteristics, impingement condition, and impingement condition of the abradant particles.

Parameters affecting the slurry erosion rate were recently detailed by Javaheri et al. [6]. A summary is provided here regarding the abradant particle properties and the impingement conditions. For the particle properties, sharp angular particles cause more erosion because of easier rotation in the flow (i.e., higher kinetic energy) and punctual energy exchange during impact [13]. A power-law dependence of erosion rate on the particle size was observed since large particles transfer more kinetic energy and cause greater degradation [14]. An increase in the abradant hardness enhances the degradation rate. However, erosion rate reductions have been observed for high fluid viscosity and high velocity $\left(>50 \mathrm{~m} \times \mathrm{s}^{-1}\right)[15,16]$. Note that a simultaneous increase of the particles and target hardness leads to a constant erosion rate [17]. For the impingement conditions, the particle velocity and impact angle are the two main parameters. A power-law dependence between the size and the erosion rate is reported with coefficients depending on the test conditions [3,5]. If bigger particles exchange more energy than smaller ones, they can easily break when they impinge on the surface with high velocity. Small fragmented particles may follow the streamline, while larger particles may generate secondary impacts inside or outside the crater [18]. The slurry erosion rate is also affected by the impingement angle and depends on the target ductility. For ductile materials such as carbon steel, the maximum erosion is often reported between $30^{\circ}$ and $50^{\circ}$, whereas it is about $90^{\circ}$ for brittle materials [19-21]. Besides, the sample surface morphology significantly affects the slurry erosion, shown by Chen et al. [22]. Using controlled groove geometries (V shape or $\mathrm{U}$ shape), they demonstrated that V-shape defects better resist erosion while the vortex inside grooves contributes to the degradation mechanism.

In piping systems, low carbon steels with ferrite pearlite microstructure are often used, as in the cooling system of the Fukushima Daichi power plant. In the actual situation, the cooling system contains particles abrading the pipe surface and later leading to failure. Therefore, it is interesting to characterize this material resistance under erosion-corrosion conditions. On the one hand, the flow velocity in the current piping system is lower than $5 \mathrm{~m} \times \mathrm{s}^{-1}$, which is below the considered velocity in most work (mining conditions, as an example). On the other hand, this work aimed to understand how the degradation rate evolves with different batches of particles sizes or concentrations. For this purpose, a jet cell was designed to control the flow velocity and the jet angle and experiments were designed to identify the effect of particle size and concentration on the damage. 


\section{Experimental Part}

\subsection{Metallic Substrate}

Experiments were performed on mild steel (JIS-SM400B equivalent to DIN17100) provided by Nippon Steel (Tokyo, Japan). The microstructures (surface and cross section) were observed with SEM S3000 from Hitachi (Tokyo, Japan). The chemical composition was determined by SEM-EDS from Nippon Steel inspection service and are reported in Table 1. Coupons of $2.5 \times 2.5 \mathrm{~cm}^{2}$ were extracted from $4 \mathrm{~mm}$ thick sheets. The surfaces under interest were grounded using an emery paper $\mathrm{SiC}$ grade 500 , rinsed with distilled water, and dried with pulsed air. No additional thermal or mechanical treatments were performed on the industrial sheets before tests.

Table 1. Chemical composition of SM400B determined by SEM-EDX in wt.\%. Standard values are also reported.

\begin{tabular}{cccccccc}
\hline Elements & $\mathbf{C}$ & $\mathbf{S i}$ & Mn & $\mathbf{C r}$ & $\mathbf{P}$ & $\mathbf{S}$ & $\mathbf{F e}$ \\
\hline sample & 0.14 & 0.21 & 0.85 & 0.02 & 0.012 & 0.006 & Bal. \\
\hline Standard & $<0.2$ & $<0.35$ & $0.6-1.4$ & Not specified & $<0.035$ & $<0.035$ & \\
\hline
\end{tabular}

Figure 1 shows the two-phase microstructure of the material after a Nital etching. The ferrite grain size was about $20 \mu \mathrm{m} \pm 10 \mu \mathrm{m}$ without preferential orientation after rolling. Perlite surface covered about $15 \%$ of the surface, as shown in Figure 1, when treated with public ImageJ software (V1.53, Bethesda, MD, USA). Micro Vickers' hardness of $220 \pm 20$ was measured on polished surfaces after OPS preparation and chemical etching. Then, the erosion-corrosion samples were fixed to the sample holder and then mounted in the testing cell. Metallic surfaces out of interest were protected with a varnish to avoid edge corrosion or back-surface corrosion. Note that a new sample was used for each tested condition.

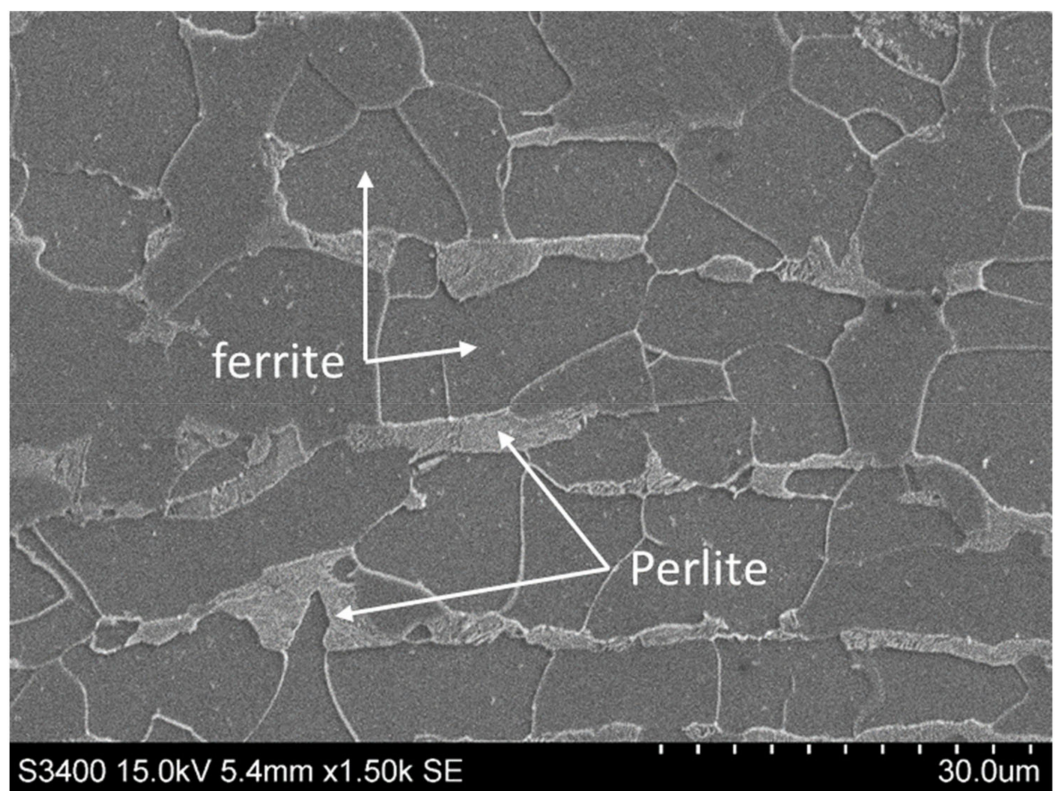

Figure 1. Ferrite perlite microstructure of SM400B after chemical etching in Nital solution.

\subsection{Corrosive Solution and Abradant}

The fluid for Flow Erosion Corrosion (FEC) or flow corrosion (FC) tests were performed with an aerated $0.005 \mathrm{M} \mathrm{Na}_{2} \mathrm{SO}_{4}$ solution with a natural $\mathrm{pH}$ of $6.5\left(\mathrm{~T}_{\text {solution }}=33^{\circ} \mathrm{C}\right)$. This solution was used to limit ohmic drop during electrochemical measurements and mitigate aggressivity of the solution to enhance the effect of abradant impacts. 
Alumina particles (As-one, Japan) were selected as the abradant. They were used in different concentrations and sizes to modify the solution turbidity and the total suspended solids. Figure 2 shows their morphologies (left column). Whatever their size, particles presented sharp angles prone to cutting impacts. The right column, Figure 2, reports the size distributions of three batches of particles determined by laser granulometry measurements (LMS-3000, Malvern instrument (Malvern, UK). The smallest particle size had a $\mathrm{D}_{\mathrm{v}}(50)$ of $181 \mu \mathrm{m}$ (Figure $2 \mathrm{~b}$ ). The second batch was characterized by a $\mathrm{D}_{\mathrm{v}}(50)$ of $219 \mu \mathrm{m}$ (Figure $2 \mathrm{~d}$ ). Finally, the largest particles had a Dv(50) of $356 \mu \mathrm{m}$ (Figure 2f). Note that the second and third batches presented large size distributions. Hereafter, each abradant was labeled by its respective $D_{v}(50)$. The number of particles was roughly estimated to $1.6 \times 10^{5}, 1.4 \times 10^{5}$, and $0.2 \times 10^{5}$ units $\times \mathrm{g}^{-1}$ for $181 \mu \mathrm{m}, 219 \mu \mathrm{m}$, and $356 \mu \mathrm{m}$, respectively [23]. Note that new solution and new particles were used for each test (no solution or particle recycling was practiced here).
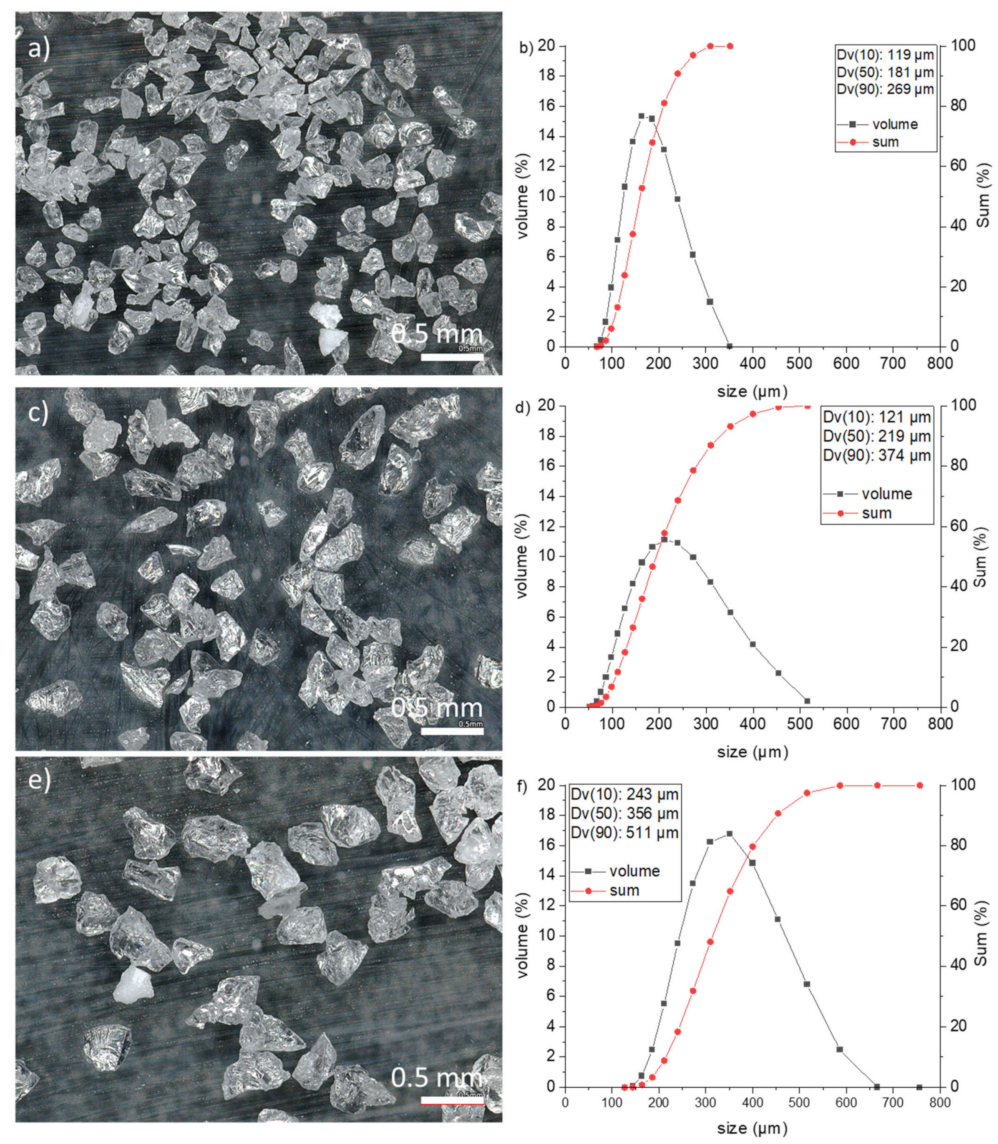

Figure 2. Optical images of $\mathrm{Al}_{2} \mathrm{O}_{3}$ particles with an average diameter of (a) $181 \mu \mathrm{m}$, (c) $219 \mu \mathrm{m}$, and (e) $356 \mu \mathrm{m}$. Respective size distributions are (b) $181 \mu \mathrm{m}$, (d) $219 \mu \mathrm{m}$, and (f) $356 \mu \mathrm{m}$.

\subsection{Electrochemical Parameters}

The mild steel was the working electrode connected to a VP300 potentiostat (Grenoble, Biologic, France). The counter electrode consisted of a graphite rod of $16 \mathrm{~cm}^{2}$, and the reference electrode was a Mercury Sulfate Electrode $(0 \mathrm{~V} / \mathrm{MSE}=+0.650 \mathrm{~V} / \mathrm{ENH})$. An ohmic drop (IR drop) of about 160 Ohm was determined by electrochemical impedance spectroscopy at $100 \mathrm{MHz}$. Polarization curves were corrected to the IR drop. The electrochemical sequence consisted of: (i) an Open Circuit Potential (OCP) of 60 min and (ii) linear sweep voltammetry (LSV). The LSV started from the OCP to a reverse potential of $-1.4 \mathrm{~V} / \mathrm{MSE}$ (partial reduction of oxide on the surface), then from $-1.4 \mathrm{~V} / \mathrm{MSE}$ to $-0.6 \mathrm{~V} / \mathrm{MSE}$. The scan rate was fixed to $1 \mathrm{mV} \times \mathrm{s}^{-1}$. The measurements were performed at least two times. Since high reproducibility was found, only one curve is displayed in the 
following. For Tafel fit analysis on LSV curves, the equivalent weight of steel was 28.25, and the density was equal to $7.7 \mathrm{~g} \times \mathrm{cm}^{-3}$.

\subsection{Flow-Corrosion and Erosion-Corrosion Experiments}

Figure 3a shows a schematic representation of the FEC cell adapted from Lopez et al. [24]. The solution flowed in a single loop by the mean of a peristaltic pump (Verderflex Vantage 5000, Eragny-sur-Oise, France). The hose was provided by Verderflex (Verdeprene LP 2.4WT, Eragny-sur-oise, France) and had a fixed length of $1 \mathrm{~m}$. The distance between the cell outlet and the pump entry and the gap between the pump exit and the nozzle inlet were kept constant to avoid pressure drop. Note that the jet pressure was not measured in this work. The flow velocity at the nozzle exit was controlled by the pump rotation and the nozzle diameter reduction (exit diameter of $4 \mathrm{~mm}$ ). With this setup, a maximum flow rate of $\sim 0.25 \mathrm{~m} \times \mathrm{h}^{-1}$ was achieved with a flow velocity of $4.8 \mathrm{~m} \times \mathrm{s}^{-1}$. The jet angle varied between $30^{\circ}$ and $90^{\circ}$. However, most of the experiments were performed either at $45^{\circ}$ or $90^{\circ}$, as explained later. The standoff distance or $d_{\text {moy }}$ (i.e., the distance between the nozzle axis outlet and the sample surface) is adjusted by controlling the distance $h$ in Figure $3 b$ with slip gauges.

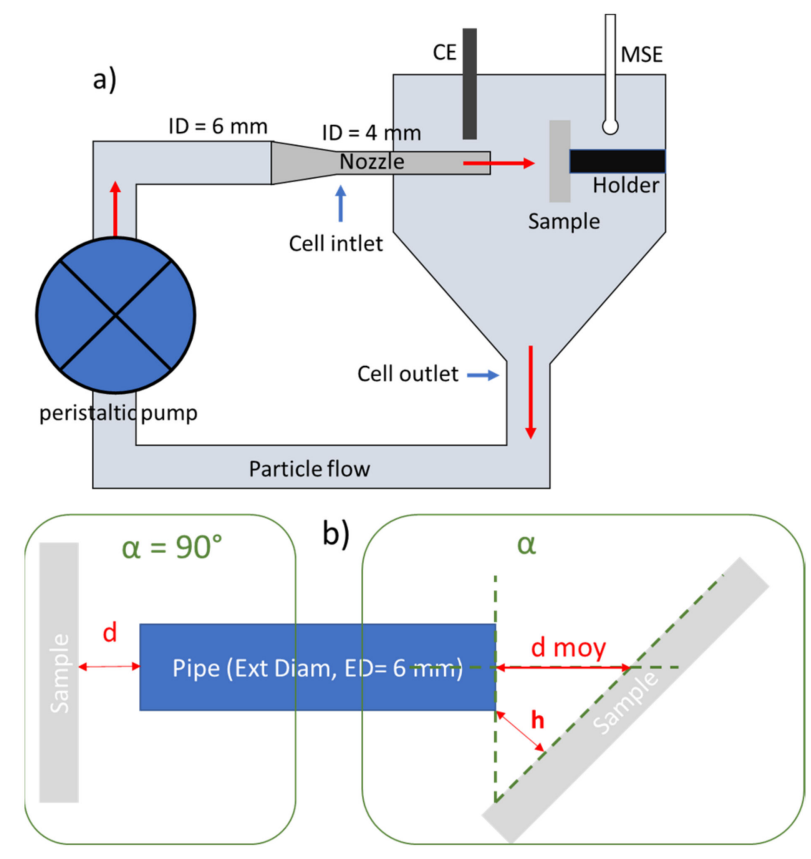

Figure 3. (a) Schematic representation of the jet corrosion cell and (b) definition of the nozzlesample distance.

For flow-corrosion experiments (solution without abradants), the erosion crater was not detectable with the optical 3D microscope; therefore, weighing analysis was applied (Equation (1)). The variation of coupon masses was recorded with a high-precision balance (MSE225S, Satorius, Gottingen, Germany, precision $0.01 \mathrm{mg}$ ). Before weighing, the protective varnish was removed in acetone to avoid the influence of possible polymer water uptake. Note that any corrosion product was found below the varnish. Moreover, the corrosion products were eliminated in the inhibiting solution of the ASTM standard G1-03.

$$
E C_{\text {weighing }}=\frac{\left(m_{i}-m_{t}\right)}{S \times\left(\frac{t}{3600}\right)} \text { in }\left[m g \times \mathrm{cm}^{2} \times h^{-1}\right]
$$

where $m_{i}$ is the initial mass of the sample (mg), $m_{t}$ is the mass of the sample after erosioncorrosion (mg), $S$ is the surface of the coupon $\left(\mathrm{cm}^{2}\right)$, and $t$ is the duration of the experiment.

3D profile measurements quantified degradation of SM400B during erosion-corrosion tests at the crater position. Optical images of the damaged surfaces were recorded with a 
3D microscope (Keyence VR5000, Osaka, Japan). The whole surface was mapped with the high-magnification mode and the $\times 160$ objective. The volume of the crater was extracted from the 3D-image analysis (Software analysis Keyence, Osaka, Japan). The mass loss was then calculated under the metal density assumption equal to $7.7 \mathrm{~g} / \mathrm{cm}^{3}$ with Equation (2).

$$
E C_{3 D \text { profile }}=\frac{7.7 \times V}{S \times\left(\frac{t}{3600}\right)} \text { in }\left[m g \times \mathrm{cm}^{2} \times h^{-1}\right]
$$

where $S$ is the surface of the coupon $\left(\mathrm{cm}^{2}\right), t$ is the duration of the experiment, and $V$ is the crater volume $\left(\mathrm{cm}^{2}\right)$.

After erosion tests, cross-sections of selected craters were prepared by embedding samples in resin, cutting with a circular saw, and surfaces were polished until OPS finishing solution. The microhardness measurement was performed according to ISO14577-1 using an ultra-micro hardness tester (DUH-211, Shimadzu, Kyoto, Japan). The indentation load of $3.2 \mathrm{mN}$ was determined to measure the ferrite phase only. The indentation hardness was converted to Vickers hardness $\left(\mathrm{HV}^{*}\right)$.

\section{Results and Discussions}

\subsection{Flow Corrosion Rate}

The influence of the flow without abrasive particles on SMB400 degradation was studied in this section. Because of the low degradation rate, degradations were not determined by 3D image analysis but by weighing. Figure 4 reports the effects of the standoff distance, the jet angle, and velocity on the mass losses. Experiments were performed in the $0.005 \mathrm{M} \mathrm{Na}_{2} \mathrm{SO}_{4}$ solution at $33{ }^{\circ} \mathrm{C}(\mathrm{pH}$ 6.5). Note that only two jet angles were tested, $90^{\circ}$ and $45^{\circ}$, since they correspond to the minimum and maximum degradation, as discussed later. For SMB400 immersed in stagnant solution, the corrosion rate was around $0.05 \mathrm{mg} \times \mathrm{cm}^{-2} \times \mathrm{h}^{-1}$ and it increased up to $0.3 \sim 0.4 \mathrm{mg} \times \mathrm{cm}^{-2} \times \mathrm{h}^{-1}$ when the solution flowed on the sample surface. For experiments performed with a jet angle of $90^{\circ}$, the mass loss decreased continuously with the standoff distance. A modification of the jet angle from $90^{\circ}$ to $45^{\circ}$ slightly increased the mass-loss rate. Finally, the flow velocity reduction has consequences of mitigating the mass loss. Zeng et al. [25] measured similar flow corrosion rates for carbon steel coupons fixed in a polymer elbow pipe.

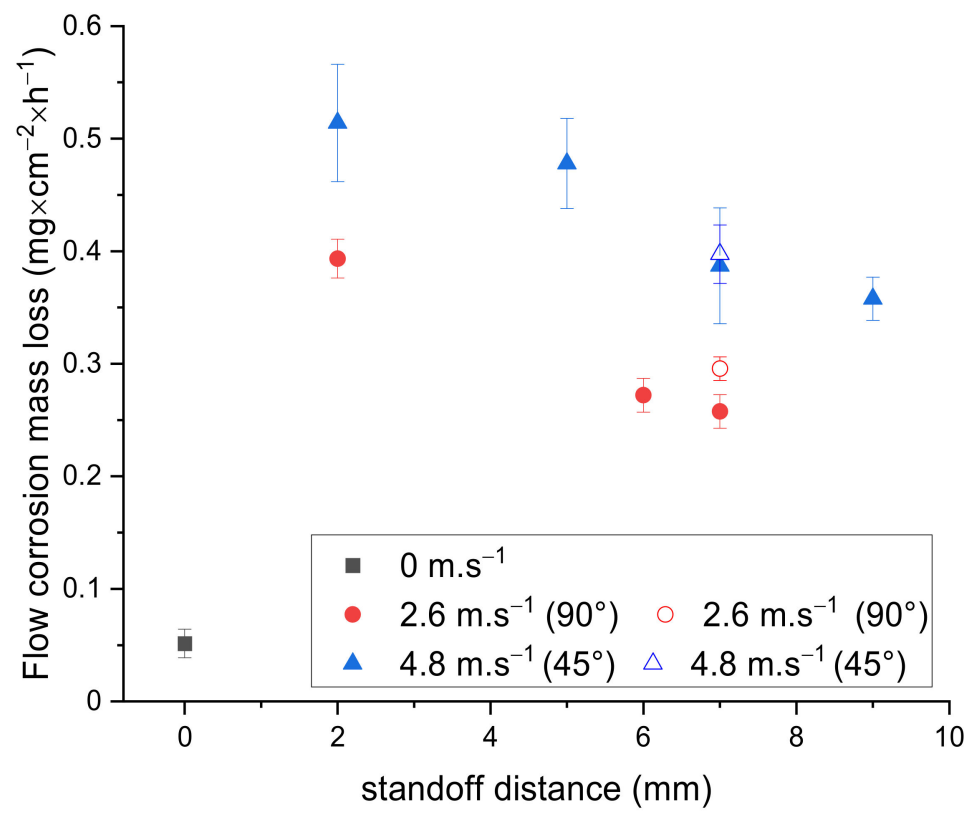

Figure 4. Flow corrosion rate as a function of the nozzle-sample standoff distance (dmoy) - the flow angle at $90^{\circ}$ and $45^{\circ}$ and two flow rates $2.6 \mathrm{~m} / \mathrm{s}$ and $4.8 \mathrm{~m} / \mathrm{s}$. 
Electrochemical characterizations (OCP and polarization curves) were carried out during these experiments, and representative OCP and LSV curves were plotted and are shown in Figure 5.
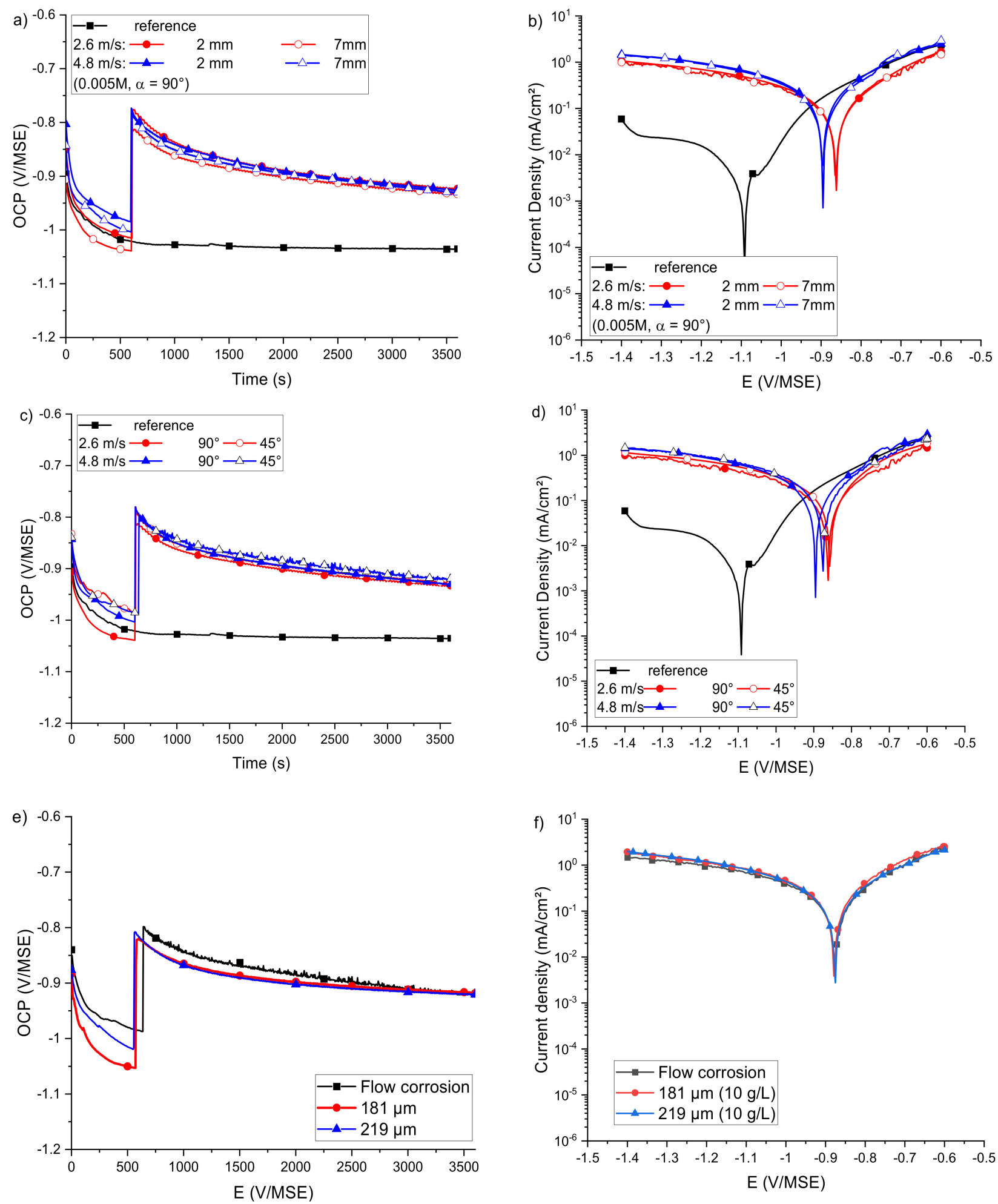

Figure 5. Influence of the flow velocity and the standoff distance on (a) the open circuit potential and (b) polarization curves on SMB400B in $5 \times 10^{-3} \mathrm{M} \mathrm{Na}_{2} \mathrm{SO}_{4} \mathrm{pH} 6.5$ solution. Influence of the jet angle on (c) OCP curves and (d) polarization curves. Effect of particles in jet flow on (e) OCP curves and (f) polarization curves. 
In stagnant conditions (i.e., fluid velocity $=0 \mathrm{~m} \times \mathrm{s}^{-1}$ ), the OCP drops towards the negative values instantly with the sample immersion (Figure 5a). This trend confirms the corrosion susceptibility of the SM400B even at a low concentration of anionic species. After $1 \mathrm{~h}, \mathrm{OCP}$ stabilized about $-1.05 \mathrm{~V} / \mathrm{MSE}$. According to the redox potential table, this mix potential corresponds to the iron dissolution $\left(\mathrm{Fe} \rightleftharpoons \mathrm{Fe}^{2+}+2 e\right)$ and the dissolved dioxygen reduction [26]. Note that the latter is under mixed charged transfer and mass transport control [27]. When fluid circulation starts after $600 \mathrm{~s}$, the OCP jumped until $-0.75 \mathrm{~V} / \mathrm{MSE}$ and slowly decreased to stabilize about $-0.9 \mathrm{~V} / \mathrm{MSE}$. This potential variation highlights a change in the kinetics of the reactions. On the LSV curves recorded (Figure 5b), the cathodic current in the jet condition was $\sim 10$ times higher than in a stagnant solution, whereas anodic current reached values measured in stagnant conditions. The dissolved dioxygen supply increased at the sample surface, the cathodic current increased, and the potential moved toward positive values [28]. The flow velocity has a slight effect on the anodic branch related to the dissolution of iron kinetic: the higher the velocity is, the higher the current density. Note that the location of the corrosion potential was somehow unusual for the experiments at $4.8 \mathrm{~m} \times \mathrm{s}^{-1}$. Indeed, a more significant shift of the potential should be expected with the cathodic current increase. It is believed that the potential inversion is related to the mechanical resistance of the iron oxides with the jet velocity.

Figure 4 also shows the role of the standoff distance and jet angle in the degradation rate. However, these trends cannot be evidenced from electrochemical OCP and LSV curves, which look similar (Figure $5 a, b$ for standoff distance and Figure $5 c, d$ for the jet angle). Therefore, Tafel fits, based on the Stern and Geary equation, were applied on LSV curves. From Tafel fits, estimation of the anodic $(\beta a)$ and cathodic $(\beta c)$ Tafel coefficients to locate the corrosion potential (Ecorr) were possible, and quantifications of the corrosion current density (Jcorr) and the corrosion rate were proposed. The mass losses were then estimated with the uniform and general corrosion mechanism assumption. EC-Lab software (from Biologic, France) was used for data treatments.

In Table 2, the results confirm that the surface reactivity was modified with the flow conditions depicted by the $\beta a$ and $\beta c$ increasing. A Tafel constant $120 \mathrm{mV} /$ decade is usually given to dissolve dioxygen reduction under mass transport limitation. An increase of $\beta c$ may result from additional surface redox couples, such as iron oxide hiding the surface for the oxygen reduction or reducing the mass transport in stirred solution in favor of charge transfer limitation $[29,30]$. $\beta$ a values were in the range of $200 \mathrm{mV} /$ decade, in agreement with the iron dissolution controlled by charge transfer and mass transport. An increase of $\beta a$ with the solution stirring is consistent with solution motion modifying the limiting boundary diffusion layer [31,32]. Finally, even if LSV curve differences are weak in the first approach, mass loss quantifications from Tafel fits confirmed an increase of degradation with the flow rate.

Table 2. Tafel Fit analysis from LSV curves (Figure 4). Errors bars are for Ecorr $\pm 0.02 \mathrm{~V}$, Jcorr $\pm 2 \mu \mathrm{A} . \mathrm{cm}^{-2}, \beta \mathrm{c}$ and $\beta a \pm 10 \mathrm{mV} /$ decade, Corrosion rate $\pm 0.03 \mathrm{~mm}$ /year, and Mass loss $\pm 0.02 \mathrm{mg} \cdot \mathrm{cm}^{-2} \cdot \mathrm{h}^{-1}$. The mass loss measured by 3D profilometry is also reported.

\begin{tabular}{|c|c|c|c|c|c|c|c|}
\hline \multirow{2}{*}{$\begin{array}{l}\text { Sample Condition } \\
\left(90^{\circ}+45^{\circ}\right)\end{array}$} & \multicolumn{6}{|c|}{ Erosion-Corrosion Rate by Electrochemical Measurements } & \multirow{2}{*}{$\begin{array}{c}\text { Weighing } \\
\text { Mass Loss } \\
\mathrm{mg} \times \mathrm{cm}^{-2} \times \mathrm{h}^{-1}\end{array}$} \\
\hline & $\begin{array}{c}\text { Ecorr } \\
\text { V/MSE }\end{array}$ & $\begin{array}{c}\text { Jcorr } \\
\mu \mathrm{A} / \mathrm{cm}^{2}\end{array}$ & $\begin{array}{c}\beta c \\
\mathrm{mV} / \mathrm{dec}\end{array}$ & $\begin{array}{c}\beta a \\
\mathrm{mV} / \mathrm{dec}\end{array}$ & $\begin{array}{l}\text { Corrosion Rate } \\
\text { mm/year }\end{array}$ & $\begin{array}{c}\text { Mass Loss } \\
\mathrm{mg} \times \mathrm{cm}^{-2} \times \mathrm{h}^{-1}\end{array}$ & \\
\hline $\begin{array}{c}0 \mathrm{~m} \times \mathrm{s}^{-1} \\
\left(90^{\circ}, 0 \mathrm{~g} \times \mathrm{L}^{-1}\right)\end{array}$ & -1.09 & 2 & 115 & 92 & 0.02 & 0.02 & Not detectable \\
\hline $\begin{array}{c}2.6 \mathrm{~m} \times \mathrm{s}^{-1} \\
\left(90^{\circ}, 0 \mathrm{~g} \times \mathrm{L}^{-1}\right)\end{array}$ & -0.86 & 88 & 297 & 171 & 1.15 & 0.08 & 0.29 \\
\hline $\begin{array}{c}4.8 \mathrm{~m} \times \mathrm{s}^{-1} \\
\left(90^{\circ}, 0 \mathrm{~g} \times \mathrm{L}^{-1}\right) \\
\end{array}$ & -0.84 & 137 & 271 & 190 & 1.65 & 0.14 & 0.39 \\
\hline $\begin{array}{c}181 \mu \mathrm{m} \\
\left(90^{\circ}, 10 \mathrm{~g} \times \mathrm{L}^{-1}\right)\end{array}$ & -0.88 & 156 & 260 & 186 & 1.87 & 0.16 & 0.64 \\
\hline $\begin{array}{c}219 \mu \mathrm{m} \\
\left(90^{\circ}, 10 \mathrm{~g} \times \mathrm{L}^{-1}\right)\end{array}$ & -0.87 & 181 & 322 & 234 & 2.18 & 0.18 & 0.83 \\
\hline
\end{tabular}


However, a difference is noticeable between mass losses estimated with Tafel extrapolations and weighing. The damage was higher with the gravimetric measurements than electrochemical measurements, whatever the experimental condition. Such deviations might come from (i) the $\beta \mathrm{a}$ and $\beta \mathrm{c}$ imprecisions leading to a corrosion rate error within a range of 50\% [33]; and (ii) the influence of Tafel constants by the close presence of reversible potentials of oxidation and reduction processes [34]. Anodic and cathodic areas established during the OCP and the cathodic potential reach during LSV may not be high enough to reduce all the oxides; therefore, the surface reactivity is influenced by local galvanic coupling affecting the Tafel extrapolation, as reported by Angst et Büchler [35]. Finally, corrosion rates determined by Tafel extrapolation consider only electrochemical reactions taking place on the whole surface. Therefore, the surface-state chemistry, including oxide, chemical dissolution of material, the production of fine metallic particles, and intermediate reactions during anodic dissolution such as oxide grow, are not considered in electrochemical measurements [36].

Optical observations after the test revealed that oxide grew even in jet flow conditions (Figure 6). The surface-optical observation reports corrosion scales randomly distributed in stagnant conditions and probably located at metallurgical defects as small precipitates or surface defects from grinding (Figure 6a). With the jet flow, oxides grow even if there is fluid pressure and streamlines at the surface [37]. It is worth noting that the oxide has a star morphology, enlightening the influence of shear forces and streamlines (Figure 6b) [38,39]. As the standoff distance increased (Figure $6 \mathrm{c}$ with $2 \mathrm{~mm}$, and Figure $6 \mathrm{~d}$ with $7 \mathrm{~mm}$ ), the streamlines diverged to the stagnation point (axis of the flow and signed by the convergent point of the oxide lines) $[40,41]$. Consequently, the oxide area expanded. Outside, localized corrosion initiated randomly as in the stagnant condition shown in Figure 6a.
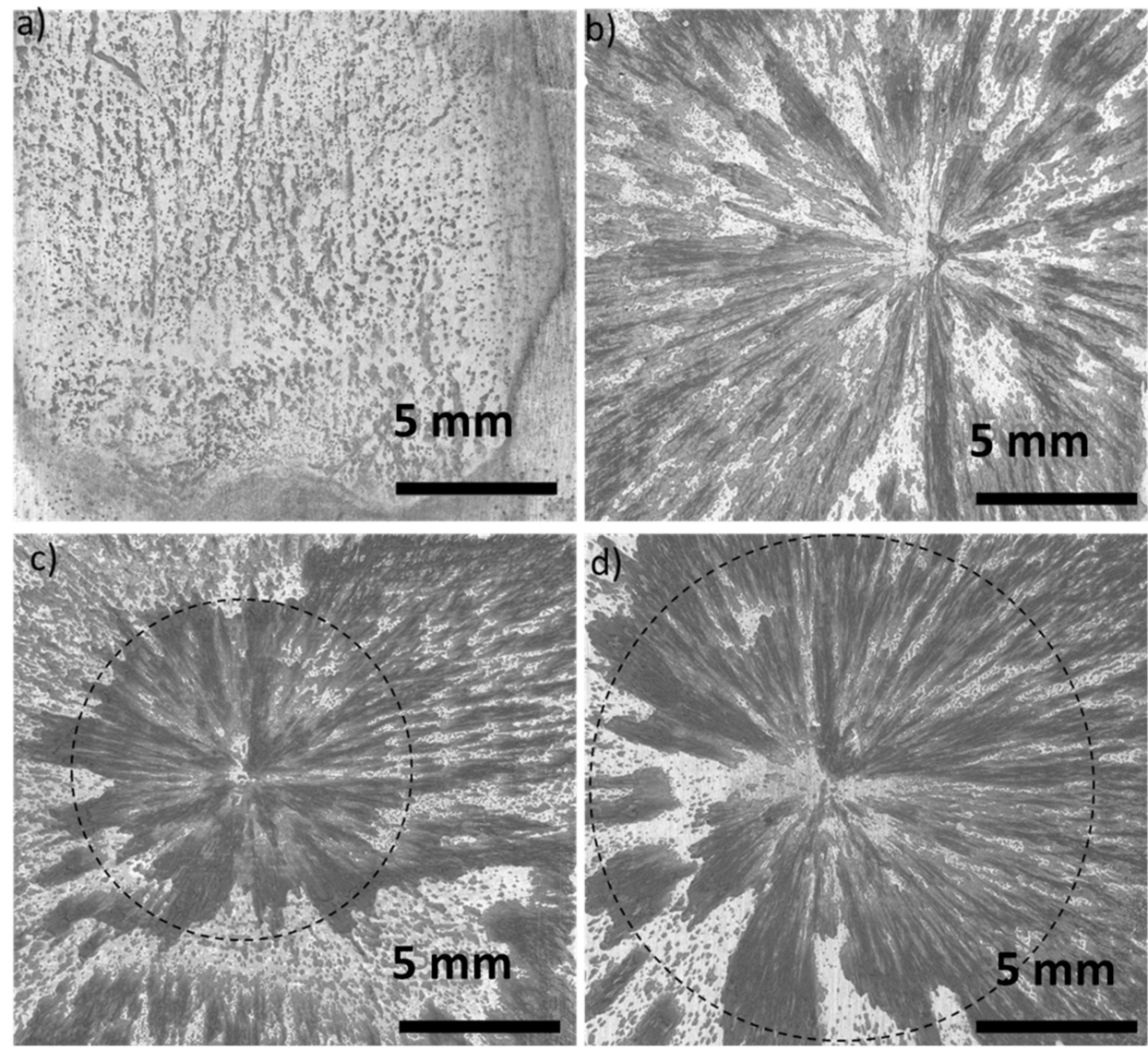

Figure 6. Optical images of the corrosion products distribution on SM400B in stagnant solution. Images after experiments with a flow rate of $4.8 \mathrm{~m} \times \mathrm{s}^{-1}$, (a) standoff distance of $7 \mathrm{~mm}$ and (b) a flow angle $45^{\circ}$, (c) a standoff distance of $2 \mathrm{~mm}\left(90^{\circ}\right)$, and (d) a standoff distance of $7 \mathrm{~mm}\left(90^{\circ}\right)$. 
These optical observations also indicate that the flow velocity was not powerful enough to detach the oxide, confirming the difference in corrosion rate between electrochemical and gravimetric measurements. Note that a change in the corrosion scale distribution was not detectable when the jet angle was tuned. No further investigation was carried out on the oxide chemistry, morphology, and thickness as the abrasive particles enhance the loss of matter and mechanically remove them.

\subsection{EC Rate versus Impact Angle and Particle Velocity}

This section evaluates the mass losses of SMB400 in the particle/aggressive solution environment as a function of (i) the experiment duration, (ii) the jet angle, and (iii) the flow velocity.

(i) Duration. Linear variations of the erosion rate with the experiment duration are usually reported in the literature [42]. However, less information is available in erosioncorrosion, even if a similar trend is expected. For this purpose, particles of $189 \mu \mathrm{m}$ impacted the SM400B surface from $40 \mathrm{~min}$ to $180 \mathrm{~min}$. These tests were carried with a particle concentration of $10 \mathrm{~g} \times \mathrm{L}^{-1}$. Results, plotted in Figure 7a, showed a quasi-linear evolution of the mass loss with the test duration, enlightening the first order of particle collision effects on the material degradation.

(ii) Angle. The literature reports a maximum erosion rate between $30^{\circ}$ and $60^{\circ}$ for a ductile material. As no universal value exists, specific experiments were performed for impact angles between $30^{\circ}$ and $90^{\circ}$ with a jet velocity of $4.6 \mathrm{~m} / \mathrm{s}$ and a concentration of $10 \mathrm{~g} \times \mathrm{L}^{-1}$ (particle size of $181 \mu \mathrm{m}$, Figure $7 \mathrm{~b}$ ). In these conditions, the maximum erosion-corrosion rate was found for an impact angle of $45^{\circ}$ while a jet angle of $90^{\circ}$ induced small losses. Al-Bukhaiti et al. [43] reported a maximum degradation at $45^{\circ}$ for mild steel (i.e., 1017 steel). As shown in Figure 7b, the subsequent experiments were performed only with two impact angles: $45^{\circ}$ and $90^{\circ}$.

(iii) Flow velocity. The effect of flow velocity (with particles) on mass losses was studied in the range of $0 \mathrm{~m} \times \mathrm{s}^{-1}$ to $5.5 \mathrm{~m} \cdot \mathrm{s}^{-1}$, knowing that the targeted velocity is $4.8 \mathrm{~m}^{-1}$. Figure $7 \mathrm{c}$ reports a negligible effect of particle impacts in the degradation rate below a jet velocity of $2.5 \mathrm{~m} \times \mathrm{s}^{-1}$. Above this threshold value, a power-law increase of the loss with the fluid and particle velocities was observed. The erosion-corrosion rate was about $1.75 \mathrm{mg} \times \mathrm{cm}^{-1} \cdot \mathrm{h}^{-1}$ at the highest jet velocity, and the degradation rate became $\sim 4$ times higher than in the case without particles. This degradation enhancement is attributed to the particle kinetic energies that depend on the flow velocity, the abradant concentration, and the particle size distribution [1,6]. In dry conditions, Wood et al. [44] developed a general equation (Equation (3)) to express the relationship between the erosion rate $(W)$ and the impact velocity of the particles $\left(V_{p}\right)$. The parameter $a$ is also known as the material/particles constant [45]. Some authors notice that this empirical equation fits well for a rapid increase in mass loss with high flow rates but could deviate for low flow velocity [46].

$$
W=m_{p} \times V_{p}^{n} \times K \times F_{\alpha}=a \times V_{p}^{n}
$$

where $m_{p}$ is the mass of particles, and $K$ is a constant depending on the material. $F_{\alpha}$ is the material-dependent function of the impact angle from 0 to $1 . n$ is the material-dependent index. This index varies between 0.34 and 4.83 depending upon the particle size, geometry, and material properties [3,5].

In this work, an excellent approximation of the experimental data was obtained for a material-dependent index $n$ around 4.39 and a material/particles constant $\sim 0.001$. These values are significantly higher than those of about 2.5 reported in dilute solution by Clark [39]. Indeed, this index is expected to increase when the particle concentration is higher than the threshold values (estimated about $10 \mathrm{wt} . \%$ by Clark), when the physical properties of abradant are significantly different to the substrate one $[7,47,48]$, and the particles are sharper and angular [47,49]. It has be to be noticed that ductility rather than hardness controls the erosion rate [50,51]. Additionally, in the case of dual phase material, 
it has been shown that cementite lamella orientation, size, and shape affect the erosion mechanism [52,53].
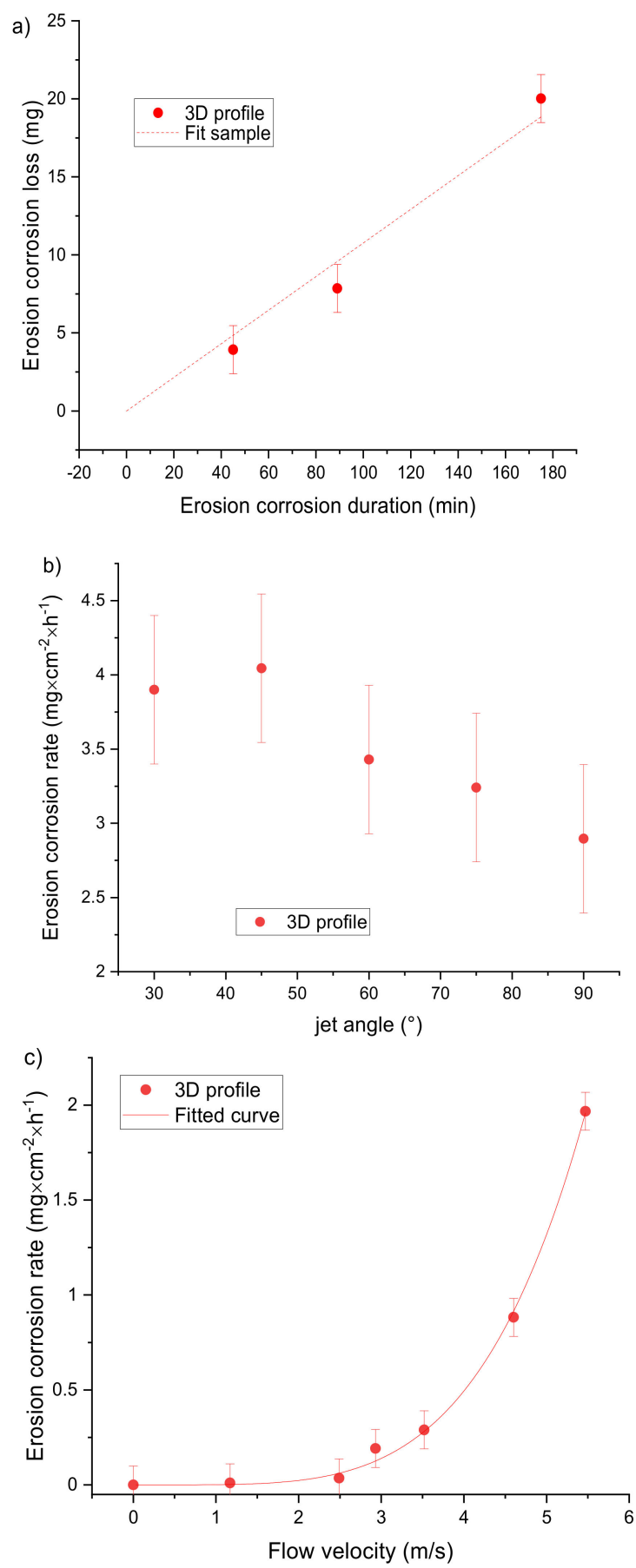

Figure 7. Mass loss rates function as (a) the experiment duration $\left(181 \mu \mathrm{m}\right.$ particle, $10 \mathrm{~g} \times \mathrm{L}^{-1}$, impingement angle of $\left.45^{\circ}\right)$, (b) the impact angle (181 $\mu \mathrm{m}$ particles, $10 \mathrm{~g} \times \mathrm{L}^{-1}$, jet velocity of $\left.4.8 \mathrm{~m} / \mathrm{s}\right)$, and (c) the flow velocities $\left(181 \mu \mathrm{m}\right.$ particles, $10 \mathrm{~g} \times \mathrm{L}^{-1}$, jet angle of $\left.45^{\circ}\right)$.

\subsection{Particle Size}

The effect of particle size on mass losses was studied at jet angles of $45^{\circ}$ and $90^{\circ}$ and a flow velocity of $4.8 \mathrm{~m} \times \mathrm{s}^{-1}$. On the one hand, the particle concentration was arbitrarily fixed at $100 \mathrm{~g} \times \mathrm{L}^{-1}$, corresponding to approximately $1.6 \times 10^{7}, 1.3 \times 10^{7}$ and $0.2 \times 10^{7}$ particles for the batches of $181 \mu \mathrm{m}, 219 \mu \mathrm{m}$, and $356 \mu \mathrm{m}$, respectively. On the other hand, approximately $2 \times 10^{6}$ particles were added in the solution for each size batch. 
Figure 8a reports a linear increase in EC with the particle diameter for a concentration of $100 \mathrm{~g} \times \mathrm{L}^{-1}$. A threshold size could be extrapolated below in which no degradation occurred $[54,55]$. In the present conditions, particles lower than $2 \mu \mathrm{m}$ may not mechanically interact with the solution according to Peng et Cao [11] and Niu et al. [40]. If they hit the surface, they are characterized by low kinetic energy and a low impact angle, leading to weak or negligible transfer energy. According to particle size analysis (Figure 2), such small particles are not present in batches; therefore, all particles may contribute to the material erosion-corrosion. Figure 8a also depicts that larger particles lead to a higher EC rate because of their higher striking efficiency and the higher energy dissipation during the collision, even if the number of particles decreased as the mean batch size increased [56]. This trend suggests that larger particles might be able to reach the fluid velocity and scratch the surface even if their Stokes number estimated at approximately 1.5, 2.3, and 3.6 for particle sizes of $181 \mu \mathrm{m}, 219 \mu \mathrm{m}$ and $356 \mu \mathrm{m}$, respectively suggest that particles may detach from the stream lines when approaching to the material surface.
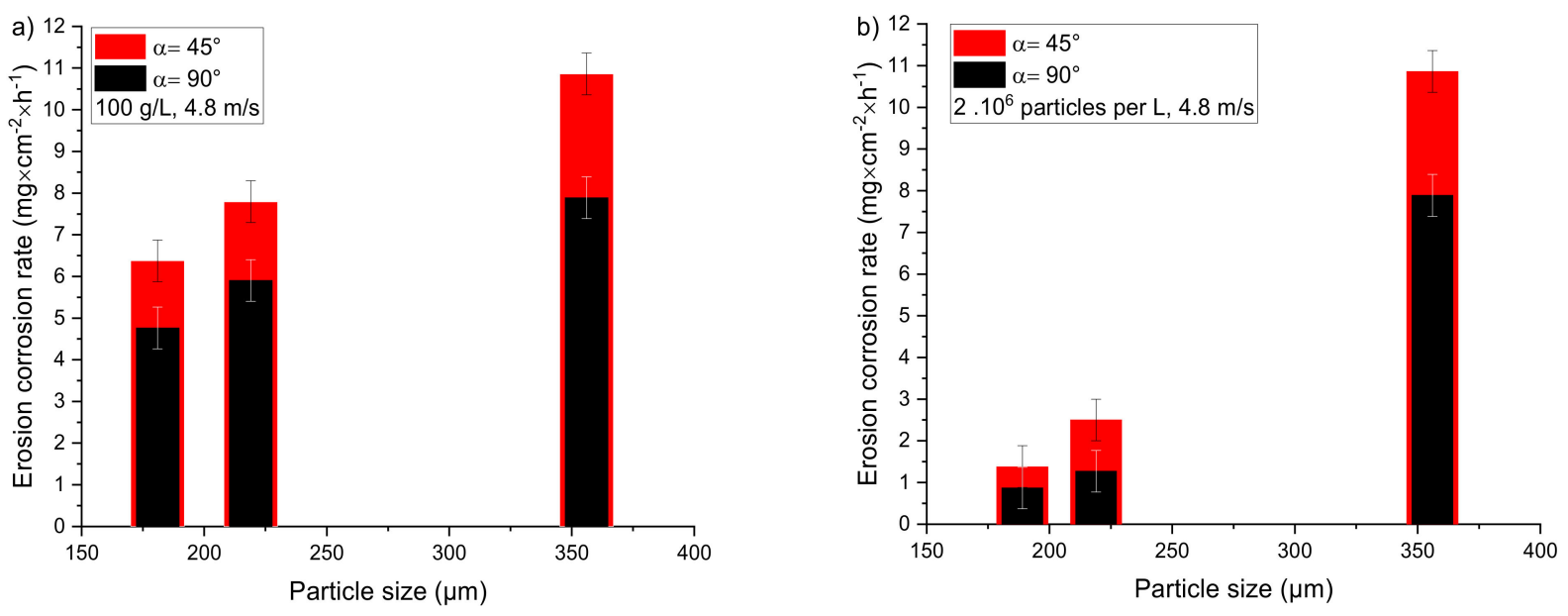

Figure 8. Effect of the particles on the mass losses for particle sizes of $181 \mu \mathrm{m}, 219 \mu \mathrm{m}$, and $356 \mu \mathrm{m}$ considering (a) a concentration of $100 \mathrm{~g} \times \mathrm{L}^{-1}$ and (b) about $2 \times 10^{6}$ particles in solution.

In a second instance, EC experiments were performed with about $2 \times 10^{6}$ particles per liter of solution. This value was calculated from the Dv values and may not correspond to a strict reality since no additional sieving was realized. This number of particles corresponds to concentrations of $12.4 \mathrm{~g} \times \mathrm{L}^{-1}, 14.4 \mathrm{~g} \times \mathrm{L}^{-1}$, and $100 \mathrm{~g} \times \mathrm{L}^{-1}$ for the particle sizes of $181 \mu \mathrm{m}, 219 \mu \mathrm{m}$, and $356 \mu \mathrm{m}$, respectively. Figure 8b shows a power-law dependence of the erosion-corrosion rate with the size as typically reported in the literature [54]: the higher the impact energy of large particles is, the more extensive the mass loss is. The effect observed in Figure 8a is amplified: the number of scars and their size decreased as the size of the abradant reduced [54]. This trend also confirms that the concentration of a batch of particles in solution is a parameter as important as the particle size.

\subsection{Particles Concentration}

The $181 \mu \mathrm{m}$ particle batch was then selected to discuss the influence of the abradant concentration on the erosion-corrosion rate of SMB400. The $181 \mu \mathrm{m}$ batch concentration varied from $0 \mathrm{~g} \times \mathrm{L}^{-1}$ up to $150 \mathrm{~g} \times \mathrm{L}^{-1}$. This higher limit was fixed to avoid dense fluid and additional forces on the pumping system. Figure 9 reports the EC rate as a function of the concentration for the jet angles of $45^{\circ}$ and $90^{\circ}$. As expected, the particle concentration increased collisions and led to a higher erosion-corrosion rate [15,40,57]. 

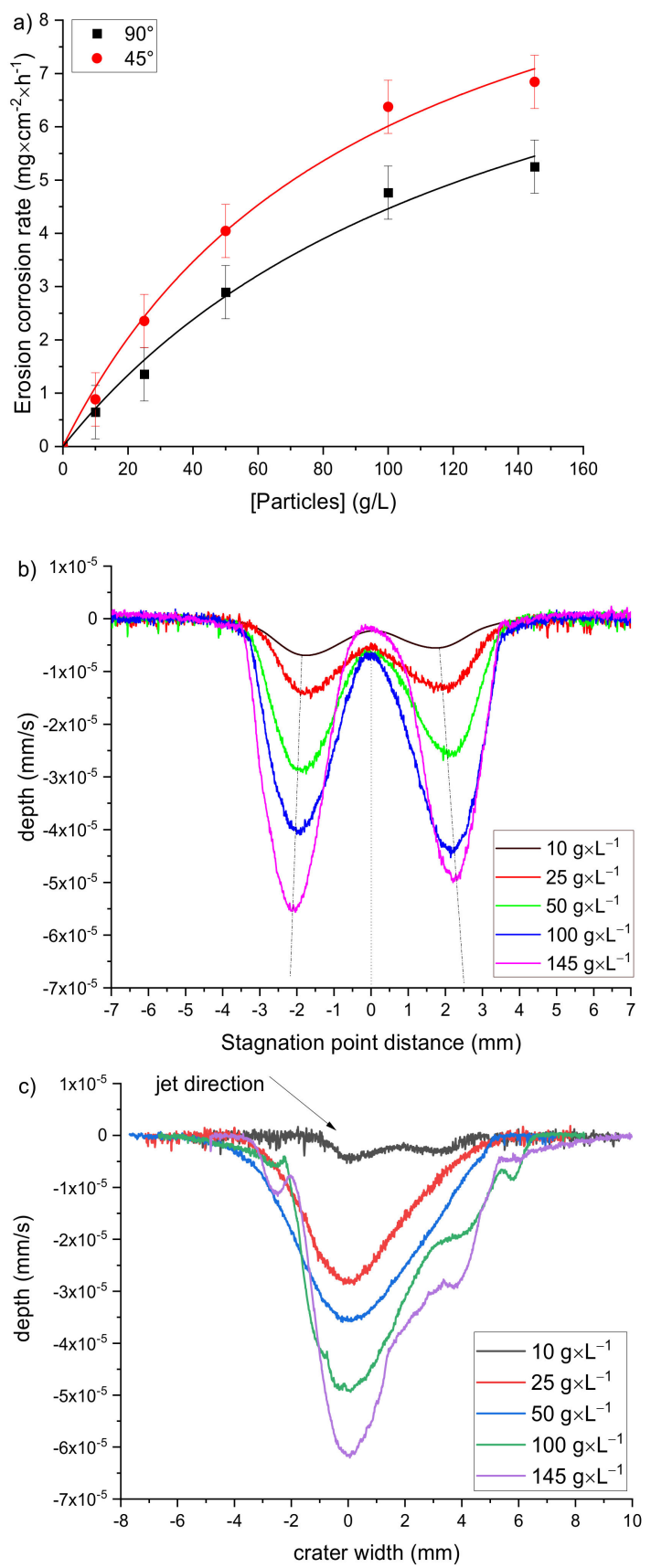

Figure 9. (a) Erosion-corrosion rate as a function of the particle concentration $(181 \mu \mathrm{m})$ for jet angles of $90^{\circ}$ and $45^{\circ}$; lines correspond to Fit results from Equation (4). Crater profiles with impingement angles of (b) $90^{\circ}$ and (c) $45^{\circ}$ (for particles $181 \mu \mathrm{m}$ batch, $4.8 \mathrm{~m} \times \mathrm{s}^{-1}$ ).

The erosion-corrosion curves showed a nonlinear trend beyond particle concentration of $50 \mathrm{~g} \times \mathrm{L}^{-1}$ irrespective of the jet angle. This slowdown is understood, considering the particle's behavior in the jet flow and over the material surface. For Zitoun et al. [58], polygonal particles have a higher chance of rotating in the jet than spherical particles. The theoretical volume occupied by one polygonal particle becomes bigger, decreasing the interparticle distance. As a result, the number of inter particles collisions rises with the concentration while the kinetic energy of the particles and the erosion rate slow down. Besides, the stagnation zone properties (thickness, pressure, etc.) are modified with the solution density, which reduces the kinetic energy of the particles [16]. Particle motion becomes limited at the surface vicinity because of the fluid density and shielding effect: rebound particles might stay longer at the surface and inside the erosion crater because of 
the arrival of new particles. Even if a stagnation point exists whatever the jet angle, the asymmetric pressure and the boundary layer thickness decrease more rapidly with a jet angle of $45^{\circ}$ and, thereby, the particles strike the surface more readily, explaining the highest degradation rate in dense solution [59,60]. Additionally, the momentum equilibration number of the particles increases with the fluid density, reflecting the particles' tendency to follow the streamlines. Consequently, the particle impact angle is modified as the number of inter particles collisions leads to a total kinetic energy reduction of the abradant and slows down the erosion-corrosion rate [16,61].

Figure $9 \mathrm{~b}, \mathrm{~d}$ reports the cross-section profiles of erosion craters for the jet angles of $45^{\circ}$ and $90^{\circ}$, respectively. Whatever the impingement angle, the maximum depth increased with the particle concentration. This trend is consistent with the increase of number impact with a high level of particles. For the jet angle of $90^{\circ}$, the cross-section profiles presented a double-V shape profile centered on the stagnation point. The erosion depth increased from the stagnation point until a maximum and then reduced for large distances. The erosion increased until 50 90 $\mathrm{g} \times \mathrm{L}^{-1}$ at the stagnation point $(\mathrm{x}=0$, Figure 9c) and decreased for higher concentrations. The wave shape profile results from the particle trajectories depending on the flow velocity, the particle size, and the solution viscosity $[24,40,62,63]$. Note that the particle size distribution and the flow velocity were kept constant between all the experiments. Small particles follow the streamlines more efficiently in a dilute solution and hit the surface with low angles and far from the stagnation point. Therefore, the tiny particles' micro-forging abilities or cutting action are weak, mainly removing the oxide layer $[40,62]$. In contrast, large particles may strike the surface close to the stagnation point, with a high angle, leading to micro-cutting and plowing until the indentation and material extrusion [43]. Larger particles may strike the surface with higher angles. As the fluid density increases, the particles with a more significant drag number decelerate more at the stagnation point and erode the surface less [39]. Secondly, the particle momentum equilibrium number increases in dense solutions. Large particles have a greater tendency to follow the streamlines reducing their impact angle [61]. Consequently, the maximum depth deviates from the stagnation point, as depicted by the dashed lines in Figure 9b [16,39]. For experiments with a jet angle of $45^{\circ}$, cross-section profiles along the jet axis are provided in Figure $9 c$, representing a V-shape profile deformed on the direction of jet exit. Both the scar width and the maximum depth increased with the concentration. On the one hand, the damage increase was consistent with the impact number enhancement. On the other hand, particle interaction increased with the concentration, as already observed at $90^{\circ}$. The particle collisions in the flow exit of the crater led to additional damages, as observed with the fluctuations on the profile between $0 \mathrm{~mm}$ to $6 \mathrm{~mm}$ in Figure 9c.

Figure 9a also suggests that the erosion-corrosion rate of SMB400 may reach a maximum at high particle concentration. To predict the maximum erosion-corrosion rate $W_{\max }$ $\left(\mathrm{mg} \times \mathrm{cm}^{-2} \times \mathrm{h}^{-1}\right)$, experimental data were fitted with Equation (4). In this relation, the concentration of the particles remained constant at each moment, and the erosion-corrosion rate and the maximum erosion-corrosion rate were proportional to the particle concentration of the particles that were able to interact with the substrate without beginning to interact between themselves.

$$
W=W_{\max } \frac{C_{\text {part }}}{C_{1 / 2}+C_{\text {part }}}
$$

where $W$ is the erosion-corrosion ( $\mathrm{mg} \times \mathrm{cm}^{-2} \times \mathrm{h}^{-1}$ ), $W_{\max }$ is the maximum erosion rate, $C_{\text {part }}$ is the particle concentration (g. $\left.\mathrm{L}^{-1}\right)$ and $C_{1 / 2}$ is the particle concentration $\left(\mathrm{g} \times \mathrm{L}^{-1}\right)$ at $W_{\max } / 2$.

The excellent agreement between the experimental and fitted data allows us to consider Equation (4) to predict the erosion-corrosion rate as a function of the particle concentration in the solution. In Table 3, a maximum erosion-corrosion rate of about $12 \mathrm{mg} . \mathrm{cm}^{-2} \cdot \mathrm{h}^{-1}$ is expected, whatever the jet angle. A similar quasi rate at high concentrations shows that the jet angle is influential in dilute solution only. In Table $3, C_{1 / 2}$ is slightly lower for 
the jet angle of $45^{\circ}$ than $90^{\circ}$. Therefore, the maximum erosion rate should be reached for lower concentrations with a jet angle of $45^{\circ}$. Moreover, this calculation suggests that a particle concentration above $192 \mathrm{~g} \times \mathrm{L}^{-1}$ (i.e., $2 \times \mathrm{C}_{1 / 2}$ ) may not significantly enhance the erosion-corrosion rate. Note that any confirmation test was carried out because of high solution density beyond $145 \mathrm{~g} \times \mathrm{L}^{-1}$.

Table 3. Result of curve fitting with Equation (4). Erosion-corrosion of SMB400 versus the particle concentration. Particle size $181 \mu \mathrm{m}$, jet velocity $4.8 \mathrm{~m} / \mathrm{s}$.

\begin{tabular}{ccccc}
\hline $\begin{array}{c}\text { Jet Angle } \\
\left({ }^{\circ}\right)\end{array}$ & $\begin{array}{c}\text { Erosion } \\
\text { Corrosion Rate }\end{array}$ & $\begin{array}{c}\mathbf{W}_{\text {max }} \\
\left(\mathbf{m g} \times \mathbf{c m}^{-\mathbf{2}} \times \mathbf{h}^{-\mathbf{1}}\right)\end{array}$ & $\begin{array}{c}\mathbf{C}_{\mathbf{1 / 2}} \\
\mathbf{( g / L )}\end{array}$ & $\begin{array}{c}\mathbf{R} \text { (Coefficient } \\
\text { of Correlation) }\end{array}$ \\
\hline 90 & & $10 \pm 3$ & $129 \pm 20$ & 0.96 \\
\hline 45 & 3D profile & $12 \pm 2$ & $95 \pm 20$ & 0.94 \\
\hline
\end{tabular}

\subsection{Erosion Corrosion Morphologies}

Figure 6 reports the oxidation surface state of SMB400 in flow conditions without particles. The addition of abradant in solution led to a surface cleaning as observed in sandblasting processes. Oxide removal occurred in the crater and surrounding area. In the absence of adherent oxide outside the crater, localized corrosion occurred because of preferential dissolution of ferrite (Figure 10a). Inside the crater, particles mechanically abraded the surface and annihilated local dissolution (Figure 10b). In the present erosioncorrosion cell, the sample holder and the nozzle acted partially as barricades to the fluid suction lines at the bottom of the cell, which caused secondary impacts on SM400B in the crater's surrounding area even if the fluid was pumped below the cell (also to prevent the particle settling). Therefore, different flow velocities and particle sizes may change the particle motions in the solution and erosion-corrosion rate outside the scar [15]. Note that the description of this process falls under the scope of this work and requires further investigations where the particle trajectories (angle, velocity, position) in the streamline have to be known $[40,62]$.
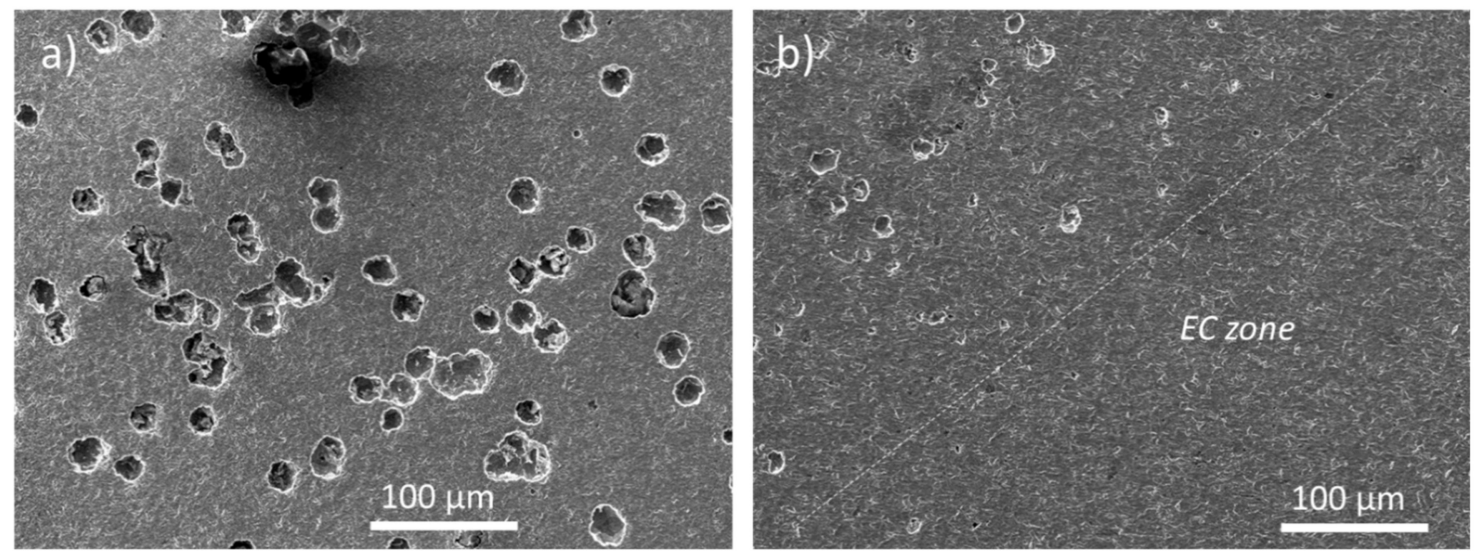

Figure 10. SEM images (a) outside the crater and (b) at the crater border. EC test $(1.5 \mathrm{~h})$ with a jet angle of $90^{\circ}$, a particle size of $181 \mu \mathrm{m}$, and a concentration of $10 \mathrm{~g} \times \mathrm{L}^{-1}$.

Erosion-corrosion degradation is a complex phenomenon depending on material parameters (abradant size, distribution, velocity for a fixed substrate) and environmental parameters such as the jet angle, the flow velocity, and the aggressiveness of the solution. If Desale et al. [54] noticed that the erosion mechanism was similar, whatever the particle size and concentration (considering dilute condition), Al-Bukhaiti et al. [43] pointed out the role of the impact angle in the erosion mechanism low-density solution. For low jet angles $\left(\sim 30^{\circ}\right)$, they considered surface fatigue and shallow plowing as predominant degradation mechanisms. A normal impingement angle $\left(90^{\circ}\right)$ concluded to an indentation 
mechanism accompanied by extruded lips removed by fatigue. At $45^{\circ}$ (which coincides with the maximum erosion in their case and in this work), erosion could be attributed to micro-cutting, deep plowing, and surface fatigue. Usually, erosion and erosion-corrosion tests are reported with a dilute concentration of abradant in solution. In this work, the particle concentration was increased until the erosion-corrosion plateau was observed. 2D cross-section profiles in Figure 9 confirm that the crater morphology depends on particle concentration. As the particle number increases in solution, the number of direct collisions and the erosion rate also increase. Surface observations were carried out after erosion corrosion tests with $10 \mathrm{~g} \times \mathrm{L}^{-1}$ and $145 \mathrm{~g} \times \mathrm{L}^{-1}$ of $181 \mu \mathrm{m}$ particles and for the both angles, $90^{\circ}$ and $45^{\circ}$.

Surface observations after the erosion-corrosion test with $10 \mathrm{~g} \times \mathrm{L}^{-1}$ of abradant are presented in Figure 11. Images labeled A are for the tests with a jet angle of $90^{\circ}$, and the photos labeled $B$ is for the tests with a jet angle of $45^{\circ}$. In the stagnation region (images A-1 and B-1), the scars do not present a particular directionality because of the complex streamline's distributions and particle behavior in this volume. The random collision with chaotic motions of particles leads to a mix of indentation and plowing deformation of the surface. Note that the effect of the flow direction (i.e., the streamline distribution at the SM400B surface) may be significant for the largest particles, as suggested by Bard et al. [64], explaining why the surfaces at $45^{\circ}$ appear more damaged.

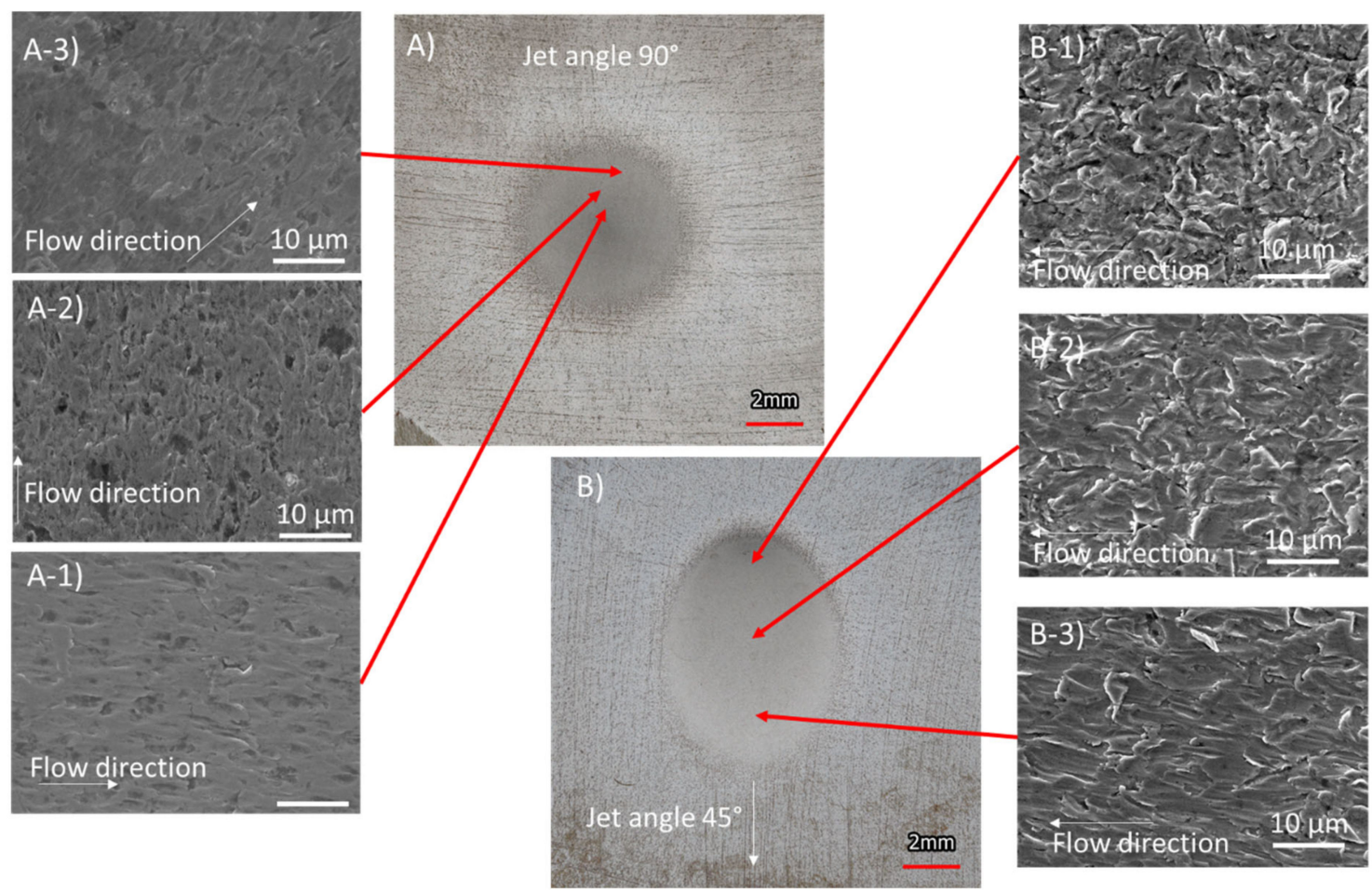

Figure 11. Optical and SEM observations of craters after erosion-corrosion test with $10 \mathrm{~g} \times \mathrm{L}^{-1}$ of particles with an impingement angle of $90^{\circ}$ (A-1 stagnation region, A-2 maximum of abrasion, A-3 exit region) and $45^{\circ}$ (pictures B-1 direct jet direction, B-2 half length of exit direction, B-3 exit region).

Outside the stagnation region and still inside the crater, the surface morphologies differ with the jet angle. For experiments at $90^{\circ}$, the directionality of the flow is not very noticeable, while it is well observed for the angle of $45^{\circ}$. The observation can be understood in terms of flow field development at the material surface, as reported by Chen et al. [22]. With a jet angle of $45^{\circ}$, the particles strike the surface and quickly move away from the collision point [19]. They remain under the influence of at the exit stream flow parallel to the jet direction. Therefore, collisions are still aligned with the stream flow favoring a degradation by micro-cutting and deep plowing. At $90^{\circ}$, the formation of double U-shape 
craters under the influence of the stagnation point changes the stream flow direction. Particles could be longer stacked, suffering from turbulent flow, leading to a secondary collision in the crater [19]. Therefore, they deflect the previous particles to their expected trajectories. In these conditions, collisions randomly occur, and no preferential deformation direction can be observed.

The augmentation of the particle's concentration favors the EC rate because of the higher number of impacts with the substrate. However, a threshold concentration was determined at about $100 \mathrm{~g} \times \mathrm{L}^{-1}$ for the particles of $181 \mu \mathrm{m}$. Below this value, an expected linear increase of the mass loss was measured, while a slowdown of EC was recorded above it. The EC reduction is related to the liquid density and viscosity heightening due to expanding the number of particles. The collision efficiency decreases, as should the kinetic energy of particles because of the reduction of free rotation volume of particles and the higher inter particles collision probability $[39,61]$. Consequently, the crater surfaces are less deformed at the microscopic scale with smaller ridges than lower particle concentrations (SEM images, Figure 12). Besides, a layer of abradant could remain on the SM400B surface at high particle concentrations, preventing the impact but causing abrasion because of this layer shearing $[65,66]$. One can also notice microscopic dimples associated with voids on optical images in Figure 12. Such defects appear gradually with the particle's concentration. Their first evidence was detected from $100 \mathrm{~g} \times \mathrm{L}^{-1}$ and $50 \mathrm{~g} \times \mathrm{L}^{-1}$ for the jet angles of $90^{\circ}$ and $45^{\circ}$. It is believed that these macroscopic surface deformations result from a modification of the local particle distribution and the average particle velocity due to the surface geometry modification and local fluid recirculation region on SM400B $[10,67,68]$.

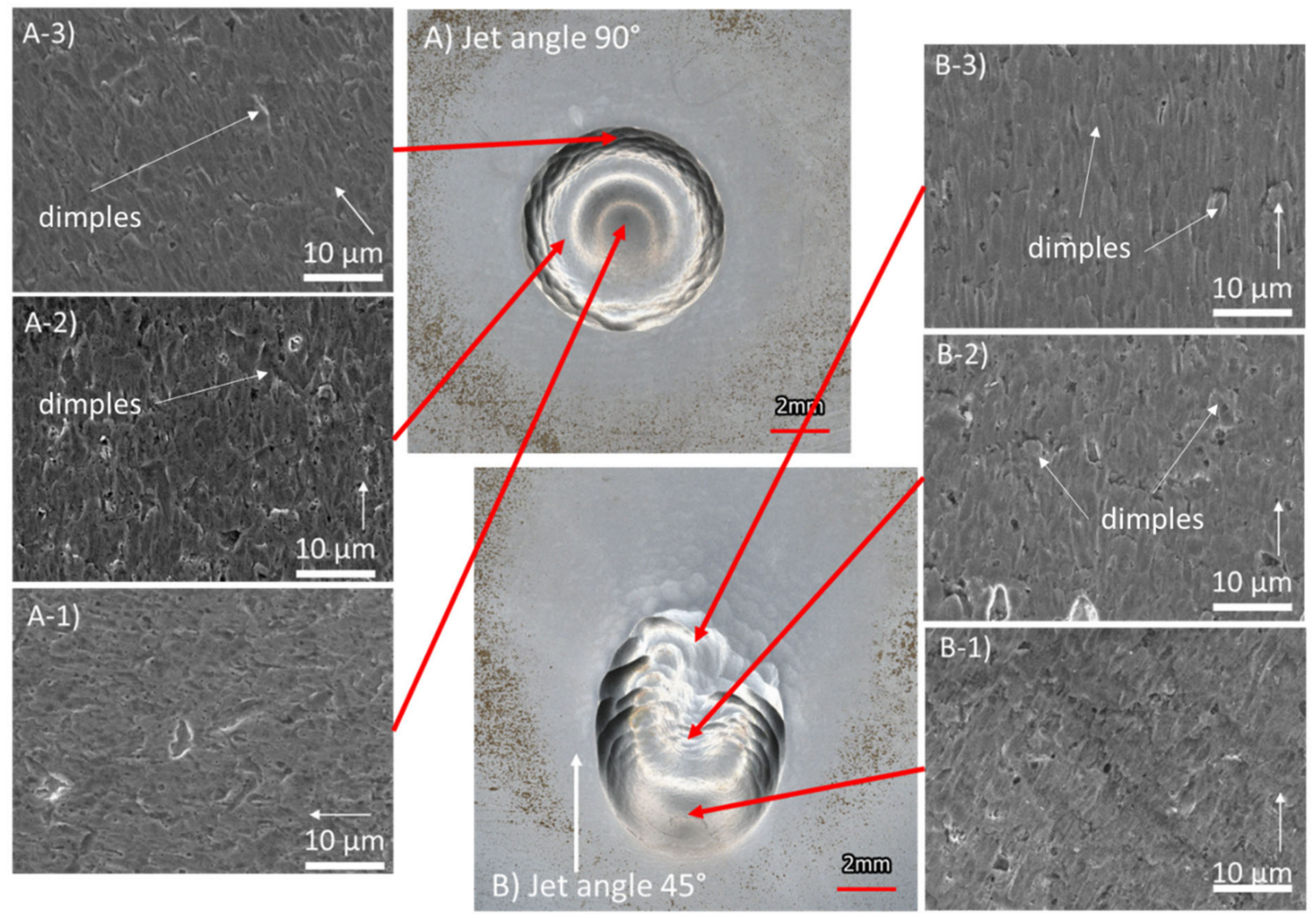

Figure 12. Optical and SEM observations of craters after erosion-corrosion test with $145 \mathrm{~g} / \mathrm{L}$ of particles with an impingement angle of $90^{\circ}$ (A-1 stagnation region, A-2 maximum of abrasion, A-3 exit region) and $45^{\circ}$ (pictures B-1 direct jet direction, B-2 half length of exit direction, B-3 exit region).

Cross-section observations were performed in the jet flow direction $\left(45^{\circ}\right)$ for samples eroded with $10 \mathrm{~g} \times \mathrm{L}^{-1}$ and $145 \mathrm{~g} \times \mathrm{L}^{-1}$ of particles. Investigations performed in the stagnation zone and the exit zone of the jet showed initial grain morphologies without evidence 
of a strain hardening layer (Figure 13). According to Krella et al. [69], strain hardening may occur for higher jet velocities than those explored in this work. Additionally, microhardness measurements were performed on the cross-sections. The validity of each hardness measurement was confirmed with a location of indentation and a force-displacement curve. The size of the indentations was approximately 1 micron and the distance between the indentations was about 30 microns (Figure 13c). In sum, 12 measurements were selected, and then the average value of 10 measurements (excluding the maximum and minimum values) was adopted to the hardness. The converted Vickers hardness obtained was $240 \mathrm{Hv}$, which is considered to be higher than that obtained in the general Vickers hardness test because the indentation load was very small. The absence of microstructural modifications and hardness gradients could arise from:

(i) limited energy transfer between particles and substrate. Indeed, the presence of a refined grain layer is usually reported for erosion tests carried out for higher particle velocities [70-72];

(ii) the cleaning process before the weighing (including but not limited to oxide removal);

(iii) the analysis scale used in this work.
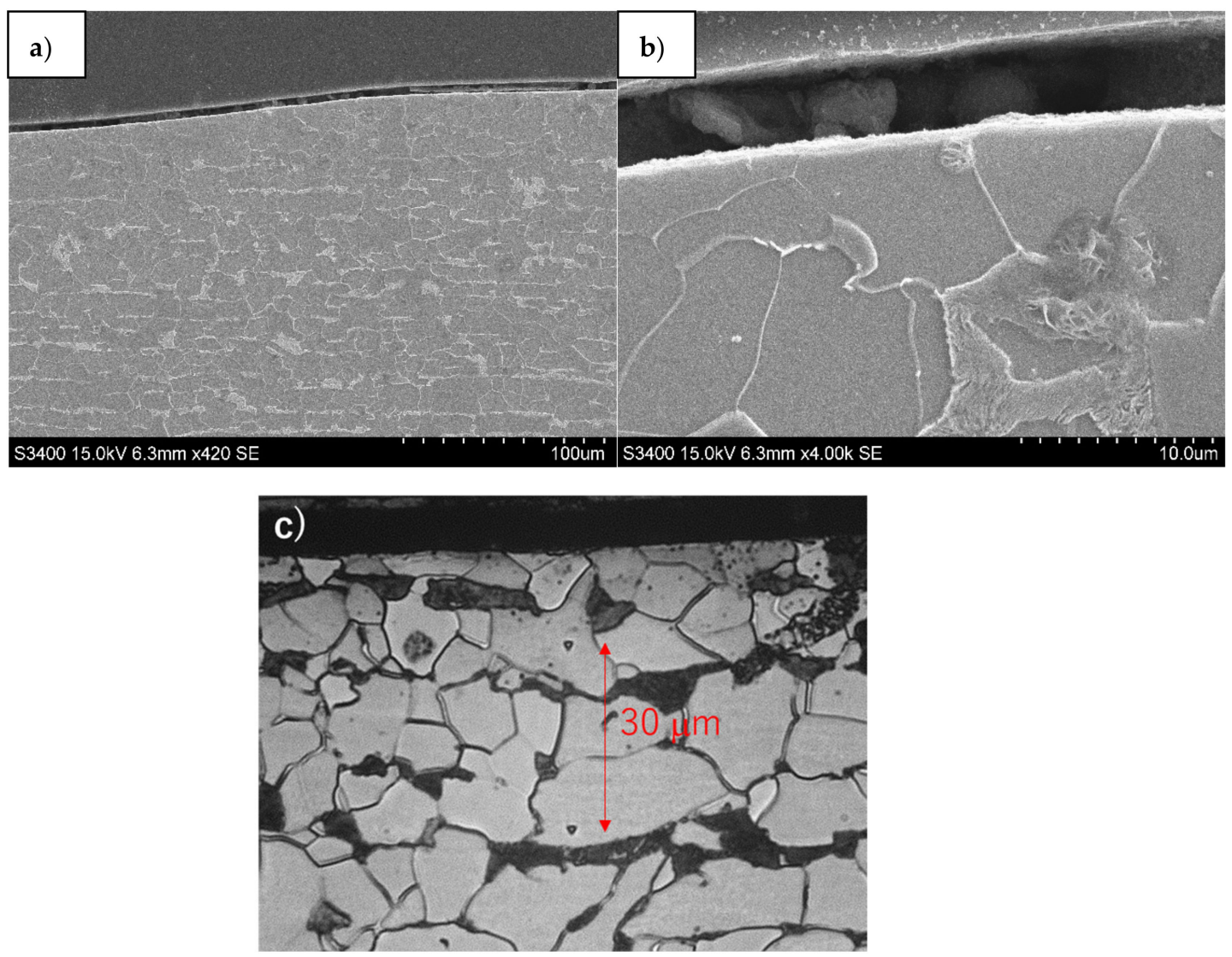

Figure 13. Example of SEM cross images of a crater generated with a jet angle of $90^{\circ}$ and a particle concentration of 100 g/L. (a) image recorded in the A-3 region, Figure 12 and (b) image caption at higher magnification. (c) Microhardness measurement under the crater area.

Therefore, further experiments should investigate the metallurgical state underneath the jet crater with limited surface treatment after erosion-corrosion tests and observations at higher magnifications from FIB cross-section preparation.

\section{Conclusions}

Based on the above investigations regarding the erosion-corrosion (EC) behavior of SM400B carbon steel, the following conclusions can be drawn: 
- The electrochemical reactivity of carbon steel only depends on the solution flow. In aerated solution, experiments operated under jet conditions presented more anodic behavior and higher cathodic currents due to the higher contribution of the dissolved oxygen reduction. When particles were added to the jet flow, no significant modifications of the electrochemical behavior of SM400B were recorded, while Tafel fits analysis reported different flow corrosion rates.

- Maximum erosion-corrosion rate was found for a jet angle at $45^{\circ}$, whereas a minimum of EC was recorded with a jet angle of $90^{\circ}$ (angle range between $30^{\circ}$ and $90^{\circ}$ ). An increase in particle percentage in solution led to a straight raise in the mass loss. A slowdown of EC was recorded because of the high solution density that impeded the particle's impingement and modified the flow dynamic at the sample surface. The concentration threshold value (about $100 \mathrm{~g} / \mathrm{L}$ for the particle size of $181 \mu \mathrm{m}$ ) was determined using Equation (4).

- $\quad$ An increase in the particle size promoted the EC rate. A linear trend was detected with fixed particle mass, while an exponential growth was found for a set number of particles in the solution.

Results also showed the generation of dimples for concentrations higher than $100 \mathrm{~g} \times \mathrm{L}^{-1}$ (jet angle $90^{\circ}$ ) and $50 \mathrm{~g} \times \mathrm{L}^{-1}$ (jet angle $45^{\circ}$ ). In contrast, the crater surfaces appeared less damaged at higher particle concentrations. Further investigations are needed to understand the generation of these dimples, combining the jet angle and particle concentration. Additionally, more precise analysis is required to confirm the absence of a grain-refined layer generated under the particles using EBSD analysis.

Author Contributions: Conceptualization, N.M. and H.A.; methodology, N.M.; investigation, C.R.; writing — original draft preparation, N.M. and H.A.; writing—review and editing, N.M., H.A., Y.W., B.N.; funding acquisition, N.M., H.A., Y.W., B.N. All authors have read and agreed to the published version of the manuscript.

Funding: PYRAMID project founded by ANR-17-CE08-0046 and JPMX 17D17823985.

Institutional Review Board Statement: Not applicable.

Informed Consent Statement: Not applicable.

Data Availability Statement: Data can be provided upon request.

Acknowledgments: This work was performed in the framework of the PYRAMID project (Piping sYstem, Risk management based on wAll thinning MonItoring and preDiction), which the French National Agency of Research supports. (ANR-17-CE08-0046). This study is the result of "Piping System, Risk Management based on Wall Thinning Monitoring and Prediction (JPMX 17D17823985)" carried out under the Center of World Intelligence Project for Nuclear S\&T and Human Resource Development by the Ministry of Education, Culture, Sports, Science and Technology of Japan. The authors want to thank A. Hashimoto for his help with SEM observation and microhardness measurements and analysis. C. Rasse acknowledged the JASSO (Japan) for his scholarship in Japan.

Conflicts of Interest: The authors declare no conflict of interest.

\section{References}

1. Zheng, Z.B.; Zheng, Y.G.; Zhou, X.; He, S.Y.; Sun, W.H.; Wang, J.Q. Determination of the critical flow velocities for erosioncorrosion of passive materials under impingement by $\mathrm{NaCl}$ solution containing sand. Corros. Sci. 2014, 88, 187-196. [CrossRef]

2. Watson, S.W.; Friedersdorf, F.J.; Madsen, B.W.; Cramer, S.D. Methods of measuring wear-corrosion synergism. Wear 1995, 181, 476-484. [CrossRef]

3. Alam, T.; Islam, M.A.; Farhat, Z.N. Slurry Erosion of Pipeline Steel: Effect of Velocity and Microstructure. J. Tribol. $2016,138$. [CrossRef]

4. Buszko, M.H.; Krella, A.K. Slurry Erosion-Design of Test Devices. Adv. Mater. Sci. 2017, 17, 5-17. [CrossRef]

5. Truscott, G.F. A literature survey on abrasive wear in hydraulic machinery. Wear 1972, 20, 29-50. [CrossRef]

6. Javaheri, V.; Porter, D.; Kuokkala, V.-T. Slurry erosion of steel-Review of tests, mechanisms and materials. Wear 2018, 408-409, 248-273. [CrossRef]

7. Desale, G.R.; Gandhi, B.K.; Jain, S.C. Effect of erodent properties on erosion wear of ductile type materials. Wear 2006, 261, 914-921. [CrossRef] 
8. Wood, R.J.K.; Jones, T.F.; Ganeshalingam, J.; Miles, N.J. Comparison of predicted and experimental erosion estimates in slurry ducts. Wear 2004, 256, 937-947. [CrossRef]

9. Aguirre, J.; Walczak, M.; Rohwerder, M. The mechanism of erosion-corrosion of API X65 steel under turbulent slurry flow: Effect of nominal flow velocity and oxygen content. Wear 2019, 438-439, 203053. [CrossRef]

10. Zhang, Y.; Reuterfors, E.P.; McLaury, B.S.; Shirazi, S.A.; Rybicki, E.F. Comparison of computed and measured particle velocities and erosion in water and air flows. Wear 2007, 263, 330-338. [CrossRef]

11. Peng, W.; Cao, X. Numerical simulation of solid particle erosion in pipe bends for liquid-solid flow. Powder Technol. 2016, 294, 266-279. [CrossRef]

12. Owen, J.; Ducker, E.; Huggan, M.; Ramsey, C.; Neville, A.; Barker, R. Design of an elbow for integrated gravimetric, electrochemical and acoustic emission measurements in erosion-corrosion pipe flow environments. Wear 2019, 428-429, 76-84. [CrossRef]

13. Levy, A.V.; Chik, P. The effects of erodent composition and shape on the erosion of steel. Wear 1983, 89, 151-162. [CrossRef]

14. Sinha, S.L.; Dewangan, S.K.; Sharma, A. A review on particulate slurry erosive wear of industrial materials: In context with pipeline transportation of mineral-slurry. Part. Sci. Technol. 2017, 35, 103-118. [CrossRef]

15. Kesana, N.R.; Throneberry, J.M.; McLaury, B.S.; Shirazi, S.A.; Rybicki, E.F. Effect of Particle Size and Liquid Viscosity on Erosion in Annular and Slug Flow. J. Energy Resour. Technol. 2014, 136. [CrossRef]

16. Kowsari, K.; James, D.F.; Papini, M.; Spelt, J.K. The effects of dilute polymer solution elasticity and viscosity on abrasive slurry jet micro-machining of glass. Wear 2014, 309, 112-119. [CrossRef]

17. Levin, M.; Wiklund, P.; Leygraf, C. Bioorganic compounds as copper corrosion inhibitors in hydrocarbon media. Corros. Sci. 2012, 58, 104-114. [CrossRef]

18. Tilly, G.P. A two stage mechanism of ductile erosion. Wear 1973, 23, 87-96. [CrossRef]

19. Islam, M.A.; Farhat, Z.N. Effect of impact angle and velocity on erosion of API X42 pipeline steel under high abrasive feed rate. Wear 2014, 311, 180-190. [CrossRef]

20. Clark, H.M.; Wong, K.K. Impact angle, particle energy and mass loss in erosion by dilute slurries. Wear 1995, 186, 454-464. [CrossRef]

21. Smith, A.J.; Stratmann, M.; Hassel, A.W. Investigation of the effect of impingement angle on tribocorrosion using single impacts. Electrochim. Acta 2006, 51, 6521-6526. [CrossRef]

22. Chen, Z.X.; Hu, H.X.; Zheng, Y.G.; Guo, X.M. Effect of groove microstructure on slurry erosion in the liquid-solid two-phase flow. Wear 2021, 466, 203561. [CrossRef]

23. Hogg, R. A Spheroid Model for the Role of Shape in Particle Size Analysis. KONA Powder Part. J. 2015, 32, 227-235. [CrossRef]

24. López, D.M.; Falleiros, N.A.; Tschiptschin, A.P. Use of Electrochemical Tests for Assessment of the Effect of Erosive Particle Size on the Erosion-Corrosion Behaviour of AISI 304L Austenitic Stainless Steel. Mater. Res. 2016, 19, 451-458. [CrossRef]

25. Zeng, L.; Zhang, G.A.; Guo, X.P. Erosion-corrosion at different locations of X65 carbon steel elbow. Corros. Sci. 2014, 85, 318-330. [CrossRef]

26. Liu, X.; MacDonald, D.D.; Wang, M.; Xu, Y. Effect of dissolved oxygen, temperature, and pH on polarization behavior of carbon steel in simulated concrete pore solution. Electrochim. Acta 2021, 366, 137437. [CrossRef]

27. Bateni, M.R.; Szpunar, J.A.; Wang, X.; Li, D.Y. Wear and corrosion wear of medium carbon steel and 304 stainless steel. Wear 2006, 260, 116-122. [CrossRef]

28. Romaine, A.; Crozet, M.; Mary, N.; Normand, B.; Chassagne, M.; Dufour, F. Importance of the surface and environmental conditions on the corrosion behavior of brass, steel and brass coated steel wires and brass coated steel cords. Corros. Sci. 2020, 177, 108966. [CrossRef]

29. Kapałka, A.; Fóti, G.; Comninellis, C. Determination of the Tafel slope for oxygen evolution on boron-doped diamond electrodes. Electrochem. Commun. 2008, 10, 607-610. [CrossRef]

30. Babić, R.; Metikoš-Huković, M. Oxygen reduction on stainless steel. J. Appl. Electrochem. 1993, 23, 352-357. [CrossRef]

31. Bockris, J.O.; Drazic, D.; Despic, A.R. The electrode kinetics of the deposition and dissolution of iron. Electrochim. Acta 1961, 4 , 325-361. [CrossRef]

32. Foroulis, Z.A. The Kinetics of Anodic Dissolution of Iron in High Purity Water. Corros. Eng. 1979, 28, 10-17. [CrossRef]

33. Stern, M.; Weisert, E.D. Experimental observations on the relation between polarization resistance and corrosion rate. Proc. Am. Soc. Test. Mater. 1959, 18, 1280.

34. Mansfeld, F.; Oldham, K.B. A modification of the Stern-Geary linear polarization equation. Corros. Sci. 1971, 11, 787-796. [CrossRef]

35. Angst, U.; Büchler, M. On the applicability of the Stern-Geary relationship to determine instantaneous corrosion rates in macro-cell corrosion. Mater. Corros. 2015, 66, 1017-1028. [CrossRef]

36. García-Galvan, F.R.; Fajardo, S.; Barranco, V.; Feliu, S. Experimental Apparent Stern-Geary Coefficients for AZ31B Mg Alloy in Physiological Body Fluids for Accurate Corrosion Rate Determination. Metals 2021, 11, 391. [CrossRef]

37. Hloch, S.; Srivastava, M.; Nag, A.; Müller, M.; Hromasová, M.; Svobodová, J.; Kruml, T.; Chlupová, A. Effect of pressure of pulsating water jet moving along stair trajectory on erosion depth, surface morphology and microhardness. Wear 2020, $452,203278$. [CrossRef]

38. Hojo, H.; Tsuda, K.; Yabu, T. Erosion damage of polymeric material by slurry. Wear 1986, 112, 17-28. [CrossRef]

39. Clark, H.M. The influence of the flow field in slurry erosion. Wear 1992, 152, 223-240. [CrossRef] 
40. Niu, C.-S.T.Y. Simulation of Erosion by the Dilute Particulate Flow Impact. Numer. Heat Transf. Part Appl. 2000, 37, 167-187. [CrossRef]

41. Fan, J.M.; Fan, C.M.; Wang, J. Flow Dynamic Simulation of Micro Abrasive Water Jet. Solid State Phenom. 2011, 175, 171-176. [CrossRef]

42. Madsen, B.W. Measurement of erosion-corrosion synergism with a slurry wear test apparatus. Wear 1988, 123, 127-142. [CrossRef]

43. Al-Bukhaiti, M.A.; Ahmed, S.M.; Badran, F.M.F.; Emara, K.M. Effect of impingement angle on slurry erosion behaviour and mechanisms of 1017 steel and high-chromium white cast iron. Wear 2007, 262, 1187-1198. [CrossRef]

44. Wood, R.J.K. Erosion-corrosion interactions and their effect on marine and offshore materials. Wear 2006, 261, 1012-1023. [CrossRef]

45. Haugen, K.; Kvernvold, O.; Ronold, A.; Sandberg, R. Sand erosion of wear-resistant materials: Erosion in choke valves. Wear 1995, 186, 179-188. [CrossRef]

46. Rajahram, S.S.; Harvey, T.J.; Wood, R.J.K. Electrochemical investigation of erosion-corrosion using a slurry pot erosion tester. Tribol. Int. 2011, 44, 232-240. [CrossRef]

47. Liebhard, M.; Levy, A. The effect of erodent particle characteristics on the erosion of metals. Wear 1991, 151, 381-390. [CrossRef]

48. Torrance, A.A. An explanation of the hardness differential needed for abrasion. Wear 1981, 68, 263-266. [CrossRef]

49. Finnie, I. Erosion of surfaces by solid particles. Wear 1960, 3, 87-103. [CrossRef]

50. Finnie, I.; McFadden, D.H. On the velocity dependence of the erosion of ductile metals by solid particles at low angles of incidence. Wear 1978, 48, 181-190. [CrossRef]

51. Divakar, M.; Agarwal, V.K.; Singh, S.N. Effect of the material surface hardness on the erosion of AISI316. Wear 2005, $259,110-117$. [CrossRef]

52. Gadhikar, A.A.; Sharma, A.; Goel, D.B.; Sharma, C.P. Effect of carbides on erosion resistance of 23-8-N steel. Bull. Mater. Sci. 2014, 37, 315-319. [CrossRef]

53. McCabe, L.P.; Sargent, G.A.; Conrad, H. Effect of microstructure on the erosion of steel by solid particles. Wear 1985, 105, 257-277. [CrossRef]

54. Desale, G.R.; Gandhi, B.K.; Jain, S.C. Particle size effects on the slurry erosion of aluminium alloy (AA 6063). Wear 2009, 266, 1066-1071. [CrossRef]

55. Iwai, Y.; Nambu, K. Slurry wear properties of pump lining materials. Wear 1997, 210, 211-219. [CrossRef]

56. Lynn, R.S.; Wong, K.K.; Clark, H.M. On the particle size effect in slurry erosion. Wear 1991, 149, 55-71. [CrossRef]

57. Gandhi, B.K.; Singh, S.N.; Seshadri, V. Study of the parametric dependence of erosion wear for the parallel flow of solid-liquid mixtures. Tribol. Int. 1999, 32, 275-282. [CrossRef]

58. Zitoun, K.B.; Sastry, S.K.; Guezennec, Y. Investigation of three dimensional interstitial velocity, solids motion, and orientation in solid-liquid flow using particle tracking velocimetry. Int. J. Multiph. Flow. 2001, 27, 1397-1414. [CrossRef]

59. Badr, H.M.; Habib, M.A.; Ben-Mansour, R.; Said, S.A.M. Numerical investigation of erosion threshold velocity in a pipe with sudden contraction. Comput. Fluids 2005, 34, 721-742. [CrossRef]

60. Garg, V.K.; Jayaraj, S. Boundary Layer Analysis for Two-Dimensional Slot Jet Impingement on Inclined Plates. J. Heat Transf. 1988, 110, 577-582. [CrossRef]

61. Humphrey, J.A.C. Fundamentals of fluid motion in erosion by solid particle impact. Int. J. Heat Fluid Flow 1990, 11, 170-195. [CrossRef]

62. Benchaita, M.T.; Griffith, P.; Rabinowicz, E. Erosion of Metallic Plate by Solid Particles Entrained in a Liquid Jet. J. Eng. Ind. 1983, 105, 215-222. [CrossRef]

63. Shademan, M.; Balachandar, R.; Roussinova, V.; Barron, R. Round impinging jets with relatively large stand-off distance. Phys. Fluids 2016, 28, 075107. [CrossRef]

64. Bard, A.J.; Parsons, R.; Jordan, J. International Union of Pure and Applied Chemistry. In Standard Potentials in Aqueous Solution, 1st ed.; Dekker, M., Ed.; New York: New York, NY, USA, 1985.

65. Tuzson, J.J. Laboratory Slurry Erosion Tests and Pump Wear Rate Calculations. J. Fluids Eng. 1984, 106, 135-140. [CrossRef]

66. Roco, M.C.; Nair, P.; Addie, G.R. Test Approach for Dense Slurry Erosion, Slurry Eros. Uses Appl. Test Methods 1987. [CrossRef]

67. Blatt, W.; Kohley, T.; Lotz, U.; Heitz, E. The Influence of Hydrodynamics on Erosion-Corrosion in Two-Phase Liquid-Particle Flow. Corrosion 1989, 45, 793-804. [CrossRef]

68. Elvery, D.G.; Bremhorst, K. Wall Pressure and Effective Wall Shear Stresses in Heat Exchanger Tube Inlets With Application to Erosion-Corrosion. J. Fluids Eng. 1997, 119, 948-953. [CrossRef]

69. Krella, A.K.; Zakrzewska, D.E.; Buszko, M.H.; Marchewicz, A. Effect of Thermal Treatment and Erosion Aggressiveness on Resistance of S235JR Steel to Cavitation and Slurry. Materials 2021, 14, 1456. [CrossRef]

70. Dalbert, V.; Mary, N.; Normand, B.; Verdu, C.; Douillard, T.; Saedlou, S. The effects of microstructures and repassivation kinetics on the tribocorrosion resistance of ferrite and ferrite-martensite stainless steels. Wear 2019, 420-421, 245-256. [CrossRef]

71. Rodríguez, E.; Flores, M.; Pérez, A.; Mercado-Solis, R.D.; González, R.; Rodríguez, J.; Valtierra, S. Erosive wear by silica sand on AISI H13 and 4140 steels. Wear 2009, 267, 2109-2115. [CrossRef]

72. Ojala, N.; Valtonen, K.; Antikainen, A.; Kemppainen, A.; Minkkinen, J.; Oja, O.; Kuokkala, V.-T. Wear performance of quenched wear resistant steels in abrasive slurry erosion. Wear 2016, 354-355, 21-31. [CrossRef] 